\title{
Isotope and REE Characterization of Groundwater Aquifers within the Aquifer Storage and Recovery Programme in Sukhothai (N.-Thailand)
}

\author{
Manussawee Hengsuwan",2, Monthon Yongprawat ${ }^{2,3}$, Klaus Simon², Bent T. Hansen ${ }^{2}$ \\ ${ }^{1}$ Department of Groundwater Resources, Bangkok, Thailand \\ ${ }^{2}$ Geoscience Center, Georg-August-University of Göttingen, Göttingen, Germany \\ ${ }^{3}$ Thailand Institute of Nuclear Technology, Nakornnayok, Thailand \\ Email: "mhengsu@gwdg.de
}

Received 9 March 2016; accepted 27 May 2016; published 30 May 2016

Copyright (C) 2016 by authors and Scientific Research Publishing Inc.

This work is licensed under the Creative Commons Attribution International License (CC BY). http://creativecommons.org/licenses/by/4.0/

(c) (i) Open Access

\begin{abstract}
Aquifer Storage and Recovery (ASR) was a pilot project for solving flood and drought problem in the northern part of Chao Phraya River basin, Thailand. This part of Thailand always faces flooding in rainy season and drought during dry season every year. The overexploitation of groundwater during dry season leads to continuously decline of water level in this area. In this project, the excessive surface water during rainy season was stored by injection of this treated surface water through recharge wells into the underground aquifers. This would serve to raise the water level, which can be extracted for use during the dry season. To assess the efficiency of the ASR process some tracers are required. The aim of this study is to prove the suitability of natural tracers to follow up the artificial recharge process; emphasis will be placed on Strontium (Sr) isotopic composition. The results showed that the change in ${ }^{87} \mathrm{Sr} /{ }^{86} \mathrm{Sr}$ ratios could be observed during an artificial recharge due to the different isotopic fingerprint of surface water and groundwater. However, the flow direction of the injected water cannot be clearly interpreted because of the limited number of monitoring wells, small distance between each monitoring well and the short duration of injection.
\end{abstract}

\section{Keywords}

Sr-Isotope, Rare Earth Elements (REE), Aquifer Storage and Recovery (ASR), Thailand

\footnotetext{
"Corresponding author.
} 


\section{Introduction}

The Upper Chao Phraya River basin is a mountainous area alternately with low land area along the river, which is located in the northern part of Thailand and covers the administrative area of Phichit, Pitsanulok and Sukhothai provinces. The basin is composed of four main sub-basins: Ping River, Wang River, Yom River and Nan River, which feed into the Chao Phraya River (Figure 1). The annual rainfall in this area ranges from 1000 to $1500 \mathrm{~mm}$ with $80 \%$ - 90\% occurring between May and October [1]. This causes flooding in rainy season and drought during dry season every year, especially in the Yom River sub-basin. The Yom River is the only river in this basin with no storage dam to control the surface water. The construction of a storage dam on Yom River basin was recommended in 1973. However, due to the high costs, long construction period and environmental impacts, the project has not been completed. The groundwater was suggested as an intermediate solution to solve the shortage problem during dry season. But in the fact, it is extensively used for agriculture [2]. The Sukhothai Groundwater Project is the first groundwater irrigation project in Thailand and is located on Sukhothai plain on both sides of the Yom River in Sukhothai province. Groundwater was extracted from more than 200 wells for agriculture covering an area of 71,000 rais $\left(113 \mathrm{~km}^{2}\right)$. In 1989 about 50 million $\mathrm{m}^{3}$ of water were pumped from the aquifer, which is higher than the safe yield value of 40 million $\mathrm{m}^{3} /$ year. The overexploitation of groundwater leads to the continuous decline of the groundwater level in this area.

In 2008, the Department of Groundwater Resources initiated a project to solve the drought problem by the Aquifer Storage and Recovery (ASR) Method, including the design and construction of an ASR station. ASR relies on storing available or excess water in an aquifer as an artificial recharge to be recovered when needed. The artificial recharge test was performed previously in 1973 for mitigation of land subsidence in the Bangkok area. The main problems which occurred during the test were clogging and outbreaks of injected water ca $10 \mathrm{~m}$ away from the recharge well [3] [4].

The aim of this study is to assess the use of strontium isotopes and rare earth elements (REE) to determine the flow paths during the artificial recharge of surface water into the aquifers. Strontium isotopes have been proven as an effective tracer because they occur naturally and are not fractionated by geochemical reactions (e.g. mineral dissolution and precipitation) [4]-[6]. The difference in strontium isotope ratios reflects the different sources of strontium, which is usually associated with the weathering source. Therefore, this strontium ratio can be used to identify mixing sources and pathways [7].

\section{Study Site}

The ASR site was constructed in Khung Yang village, Pa Kum Ko subdistrict, Sawankalok district, Sukhothai province (Figure 1). The study area consists of solid rocks including sedimentary, metamorphic, and igneous rock of various ages, namely Silurian-Devonian rocks, Carboniferous rocks, Permo-Carboniferous rocks, Permian rocks, Triassic rock, Jurassic rocks, Jurassic rocks, Upper Cretaceous-Tertiary rocks, and Quaternary basalt; cover by Quaternary sediments consisting of:

1. Quaternary flood plain deposit (Qfd) consisting of sand and gravel interbedded with clay layers. This deposit was found along the bank of Yom River, flood plains and old waterways;

2. Quaternary young terrace deposits (Qyt) or Quaternary lower terrace deposit (Qlt) consists of sandy clay, silt and various size of gravel. This deposit spreads on ground surface and under flood plain deposit;

3. Quaternary old terrace deposits (Qot)or Quaternary higher terrace deposit (Qht) consists of various sizes of gravel, gravelly and clayey sand layers. This deposit was found along mountain slopes under lower terrace and flood plain deposits [1].

The aquifers in this area can be classified according to the level of depth into two main aquifers, namely, shallow aquifer with the depth of $35-44 \mathrm{~m}$ and deep aquifer with the depth $74-83 \mathrm{~m}$ beneath the ground surface.

The ASR site consists of 8 monitoring wells (MWS) and 1 recharge well (RWS2) for the shallow aquifer. As for the deep aquifer there are 8 monitoring wells (MWD), and 1 recharge well (RWD2). Lastly, 1 water treatment plant as shown in Figure 2.

Water from the Yom River was pumped to a settling pond before entering the water treatment system. This system consists of the chemical addition of Aluminium Sulfate for precipitation, clarification through Lamella type clarifier, filtration through a sand filter and disinfection by addition of chlorine liquid compound $(\mathrm{NaOCl})$. The treated water was injected into the recharge wells by pump pressure method. After the injection was com- 


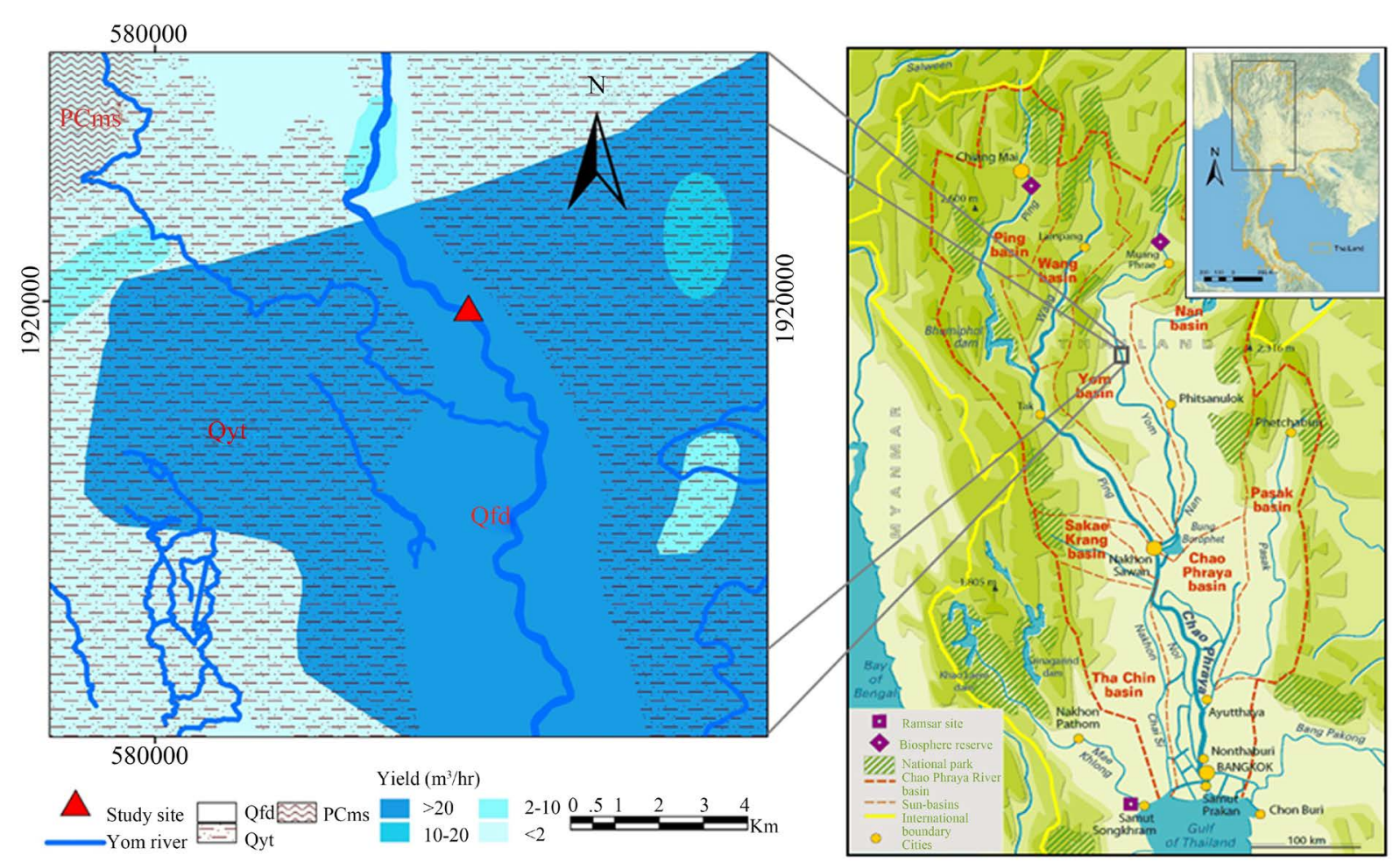

Figure 1. Hydrological map and location map of the study area, which is located in the upper Chao Phraya basin, Thailand (modified after hydrogeological map 1:50,000 of Department of Groundwater Resources and unesco.org).

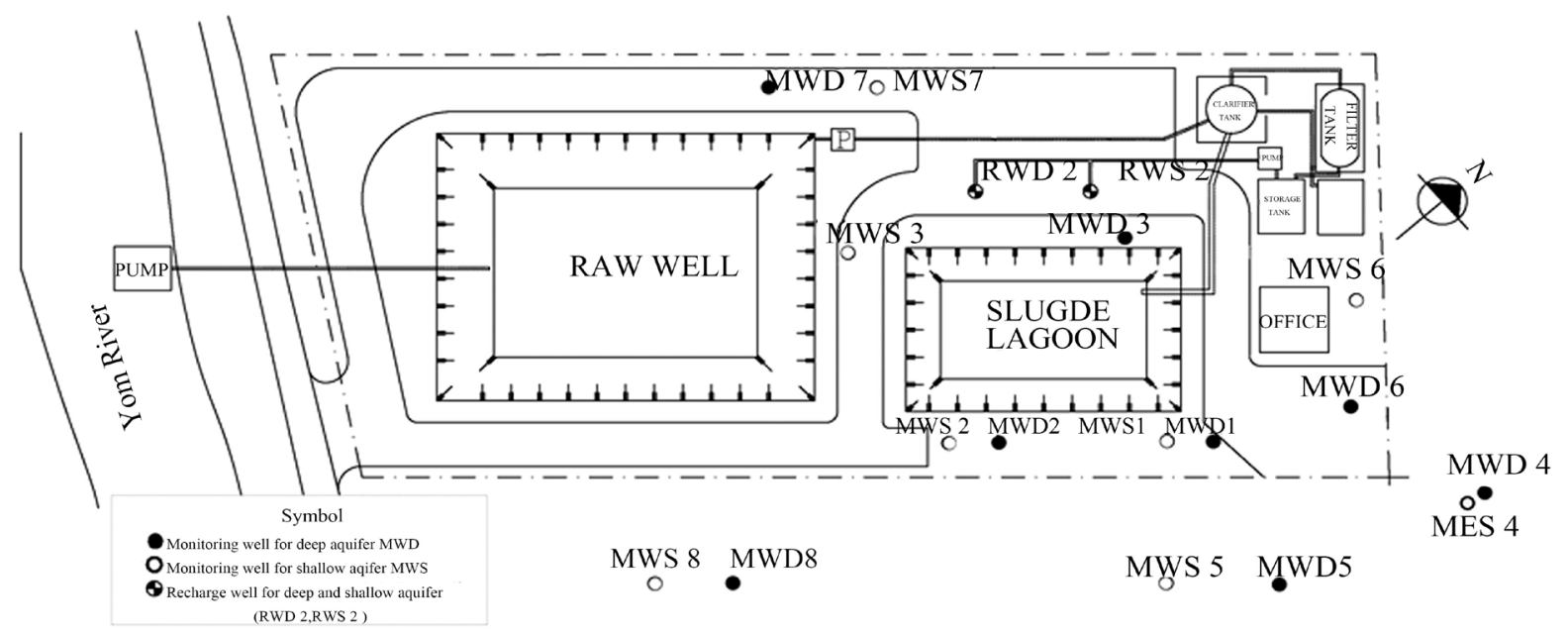

Figure 2. Map of monitoring wells and recharge wells location.

pleted, the recharged water was stored in the aquifer for a period of ca. 2 weeks as to complete the homogenization between the recharged water and original groundwater in the aquifer. The recovery of the recharged water for use was performed by extraction of 1 to 2 times the net volume of injected water by using a submersible pump, which was installed in the recharge well. In 2012 and 2013 long term ASR testing was performed by the pump pressure method. The details of long term ASR testing are summarized in Table 1.

\section{Sampling and Analytical Methods}

To obtain hydrochemical and isotopic data, groundwater samples from 8 shallow aquifer monitoring wells (MWS1-MWS8) and groundwater samples from deep aquifer monitoring wells (MWD1-MWD8) were collected. 
Table 1. Detail of sampling and recharge/extraction rate.

\begin{tabular}{|c|c|c|c|c|c|c|c|c|c|c|}
\hline \multirow{2}{*}{$\begin{array}{c}\text { ASR } \\
\text { testing } \\
\text { in year }\end{array}$} & \multirow[b]{2}{*}{ event } & \multirow[b]{2}{*}{ remark } & \multicolumn{4}{|c|}{ MWS } & \multicolumn{4}{|c|}{ MWD } \\
\hline & & & $\begin{array}{l}\text { sampling } \\
\text { date }\end{array}$ & duration & $\begin{array}{c}\text { rate of } \\
\text { injection/ } \\
\text { extraction }\end{array}$ & $\begin{array}{c}\text { total volume } \\
\text { of injection/ } \\
\text { extraction }\end{array}$ & $\begin{array}{l}\text { sampling } \\
\text { date }\end{array}$ & duration & $\begin{array}{c}\text { rate of } \\
\text { injection/ } \\
\text { extraction }\end{array}$ & $\begin{array}{c}\text { total volume } \\
\text { of injection/ } \\
\text { extraction }\end{array}$ \\
\hline \multirow[b]{2}{*}{2012} & - & $\begin{array}{l}\text { before } \\
\text { injection }\end{array}$ & - & \multirow[b]{2}{*}{-} & - & - & 16.10 .2012 & $18.10-17.11 .2$ & \multirow{2}{*}{$\begin{array}{l}50-55 \\
\mathrm{~m}^{3} / \mathrm{hr}\end{array}$} & \multirow{2}{*}{$18,949 \mathrm{~m}^{3}$} \\
\hline & - & $\begin{array}{c}\text { after } \\
\text { injection }\end{array}$ & - & & - & - & 17.11 .2012 & $\begin{array}{c}012 \\
\text { (30 days) }\end{array}$ & & \\
\hline \multirow{6}{*}{2013} & 0 & $\begin{array}{l}\text { before } \\
\text { injection }\end{array}$ & 3.08 .2013 & - & - & - & 3.08 .2013 & - & - & - \\
\hline & 1 & \multirow{3}{*}{ injection } & 12.09 .2013 & \multirow{3}{*}{$\begin{array}{c}14.08-9.10 .2013 \\
\quad(57 \text { days })\end{array}$} & \multirow{3}{*}{$\begin{array}{c}20-23 \\
\mathrm{~m}^{3} / \mathrm{hr}\end{array}$} & \multirow{3}{*}{$26,872 \mathrm{~m}^{3}$} & 28.08 .2013 & & \multirow{3}{*}{$\begin{array}{c}16-19 \\
\mathrm{~m}^{3} / \mathrm{hr}\end{array}$} & \multirow{3}{*}{$20,802 \mathrm{~m}^{3}$} \\
\hline & 2 & & 27.09 .2013 & & & & 12.09 .2013 & $\begin{array}{l}14.08-27.09 .2 \\
013 \text { (45 days) }\end{array}$ & & \\
\hline & 3 & & 9.10 .2013 & & & & 27.09 .2013 & & & \\
\hline & 4 & storage & 13.10 .2013 & $\begin{array}{c}\text { 10.10-28.10.2013 } \\
\quad(17 \text { days })\end{array}$ & & & 9.10 .2013 & $\begin{array}{l}28.09-10.10 .2 \\
013 \text { (13 days) }\end{array}$ & & \\
\hline & $\begin{array}{l}5 \\
6\end{array}$ & $\begin{array}{l}\text { recovery/ } \\
\text { extraction }\end{array}$ & $\begin{array}{c}8.11 .2013 \\
23.11 .2013\end{array}$ & $\begin{array}{c}29.10-20.11 .2013 \\
(23 \text { days })\end{array}$ & $\begin{array}{c}60-62 \\
\mathrm{~m}^{3} / \mathrm{hr}\end{array}$ & $35,471 \mathrm{~m}^{3}$ & $\begin{array}{l}19.10 .2013 \\
27.10 .2013\end{array}$ & $\begin{array}{l}11.10-27.10 .2 \\
013 \text { (17 days) }\end{array}$ & $\begin{array}{c}55-56 \\
\mathrm{~m}^{3} / \mathrm{hr}\end{array}$ & $23,507 \mathrm{~m}^{3}$ \\
\hline
\end{tabular}

In 2012 before injection started, the groundwater samples from the deep- and the shallow aquifer monitoring wells were collected for rare earth elements and Sr-isotope analyses. After the injection was completed, only groundwater samples from the deep aquifer were collected again for Sr-isotope analysis to compare the results with the ones before injection.

In 2013 groundwater samples were collected from both the shallow and the deep aquifer for analyses of Sr-isotope, stable isotopes $\left(\delta \mathrm{D}\right.$ and $\left.\delta^{18} \mathrm{O}\right)$, anions and REE. The sampling was separated into four periods, namely: before injection ( 1 time, event 0 ), during injection (3 times, event 1 - 3), aquifer storage ( 1 time, event 4) and groundwater extraction (2 times, event 5 - 6) as shown in Table 1. For comparison, samples from rain water, surface water (Yom River) and injected water were also collected. For the third event, the samples MWD4, MWD5, WWD8 were not collected as well as the samples MWS4, MWS5, WWS8 from the second and the fourth event.

All samples due to be analyzed for rare earth elements and Sr-isotope measurements were filtered through a $0.45 \mu \mathrm{m}$ membrane filter and acidified to $\mathrm{pH} 2$ with concentrated double-distilled $\mathrm{HNO}_{3}$. Water samples collected for rare earth elements were determined by ICP-MS on a PerkinElmer DRC II (Sciex, Canada) at the Geoscience Centre at The University of Göttingen (GZG, Germany). Non-acidified water samples for stable isotopes $\left(\delta \mathrm{D}\right.$ and $\left.\delta^{18} \mathrm{O}\right)$ measurement were analyzed by Liquid Scintillation Counter (Tricarb 3180 TR/SL) after electrolytic enrichment and Major anion were measured by Dionex, ICS-3000 at the Thailand Institute of Nuclear Technology (TINT). Sr concentrations and isotopic compositions were determined using a Thermo-Finnigan Triton ${ }^{\odot}$ TIMS at the Geoscience Centre at The University of Göttingen (GZG, Germany). Prior to digestion, samples were mixed with a tracer solution enriched in ${ }^{87} \mathrm{Rb}-{ }^{84} \mathrm{Sr}$. Detailed description of the analytical procedure for water samples are given in [4] and [8]. Throughout this work a value of $0.710267 \pm 0.000041(2 \sigma)$ for the NBS $987(\mathrm{n}=10)$ was observed. Instrumental mass fractionation was corrected with a ${ }^{88} \mathrm{Sr} /{ }^{86} \mathrm{Sr}$ ratio of 0.1194 using exponential law.

\section{Results}

\subsection{Initial Long Term ASR Testing by Pump Pressure Method in Year 2012}

\subsubsection{Strontium Isotopes}

Sr isotopic data are shown in Figure 3. The ${ }^{87} \mathrm{Sr} /{ }^{86} \mathrm{Sr}$ ratios of surface waters from Yom River has high Sr content compared to the groundwater ranging between $0.203-0.205 \mu \mathrm{g} / \mathrm{g}$ and ${ }^{87} \mathrm{Sr} /{ }^{86} \mathrm{Sr}$ ratios ranging from 0.70920 to 0.70944 . Sr content and ${ }^{87} \mathrm{Sr} /{ }^{86} \mathrm{Sr}$ ratios of the injected water were $0.201 \mu \mathrm{g} / \mathrm{g}$ and 0.70929 , respectively. The 


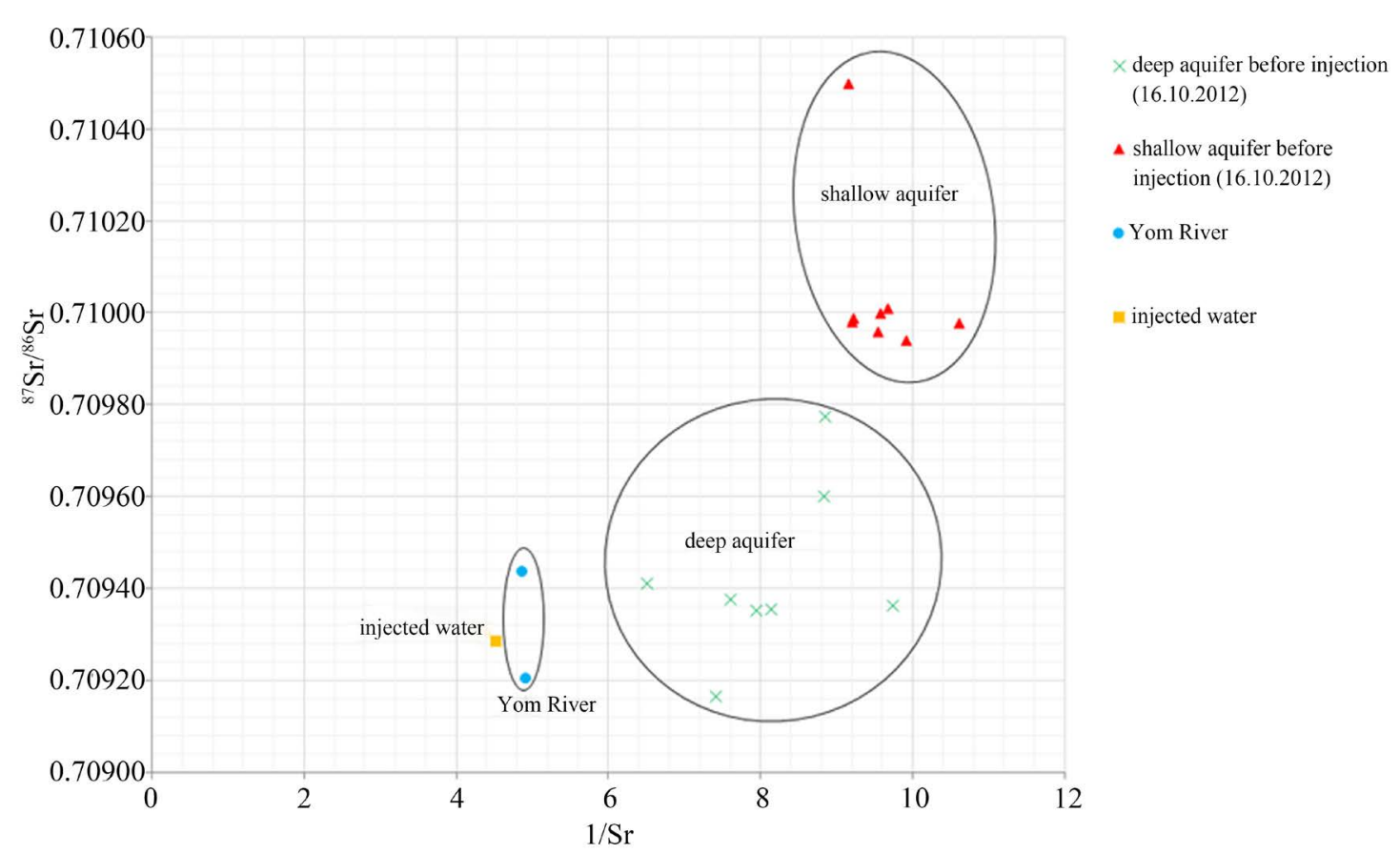

Figure 3. Correlation between ${ }^{87} \mathrm{Sr} /{ }^{86} \mathrm{Sr}$ and $1 / \mathrm{Sr}$ of shallow aquifer, deep aquifer injected water and surface water (Yom River) samples.

groundwater in the shallow aquifer can be clearly differentiated from the groundwater in the deep aquifer by $\mathrm{Sr}$ concentration and ${ }^{87} \mathrm{Sr}{ }^{86} \mathrm{Sr}$ ratios The Shallow aquifer in this study case can be classified by low $\mathrm{Sr}$ content and high ${ }^{87} \mathrm{Sr} /{ }^{86} \mathrm{Sr}$ ratios, whereas the deep aquifer exhibited a high $\mathrm{Sr}$ content and lower ${ }^{87} \mathrm{Sr} /{ }^{86} \mathrm{Sr}$ ratios.

\subsubsection{Strontium Isotope and REE in the Deep Aquifer after Initial Long Term ASR Testing}

In Figure $4,{ }^{87} \mathrm{Sr} /{ }^{86} \mathrm{Sr}$ ratios are plotted against the reciprocal $\mathrm{Sr}$ concentration of deep aquifer groundwaters before and after injection. The hypothetical mixing line for binary mixing would have a linear trend connecting the end members. Some of the data (i.e., MWD1, MWD2 and MWD6) follow a linear trend between the injected water and the groundwater samples before injection, representing the points after injection in-between, more or less close to the mixing line. The abundance of the injected water component in each groundwater sample can be calculated by equation

$$
f_{A}=\frac{\left({ }^{87} \mathrm{Sr} /{ }^{86} \mathrm{Sr}\right)_{\mathrm{C}}-\left({ }^{87} \mathrm{Sr} /{ }^{86} \mathrm{Sr}\right) \times \frac{\mathrm{Sr}_{\mathrm{B}}}{\mathrm{Sr}_{\mathrm{C}}}}{\left({ }^{87} \mathrm{Sr} /{ }^{86} \mathrm{Sr}\right)_{\mathrm{A}} \times \frac{\mathrm{Sr}_{\mathrm{A}}}{\mathrm{Sr}_{\mathrm{C}}}-\left({ }^{87} \mathrm{Sr} /{ }^{86} \mathrm{Sr}\right)_{\mathrm{B}} \times \frac{\mathrm{Sr}_{\mathrm{B}}}{\mathrm{Sr}_{\mathrm{C}}}}
$$

Subscripts A, B and C refer to injected water, groundwater sample before injection and groundwater sample after injection respectively [9].

The groundwater samples after injection in MWD1, MWD2 and MWD6 may contain about $12 \%, 9 \%$ and $21 \%$ injected water component, respectively.

In addition to the above discussed analyses, all samples were investigated for their rare earth element concentrations (Appendix). The REE concentrations show the characteristic zigzag pattern according to the Oddo-Harkins Rule [10]-[12]. The heavy REE concentrations (Eu-Lu) in most samples are below detection limit. The REE concentrations in surface water samples are relative high compared to those in groundwater samples. The REE concentration pattern can be smoothed out by normalizing the REE on an element by element to some standard. In this study, REE abundances are normalized to the upper continental crust (UCC) [13] and plotted on logarithmic scale as shown in Figure 5. Deep aquifer groundwaters and Yom River sample show a relatively flat to slightly enriched pattern in medium REE (MREE) relative to the light REE (LREE). 


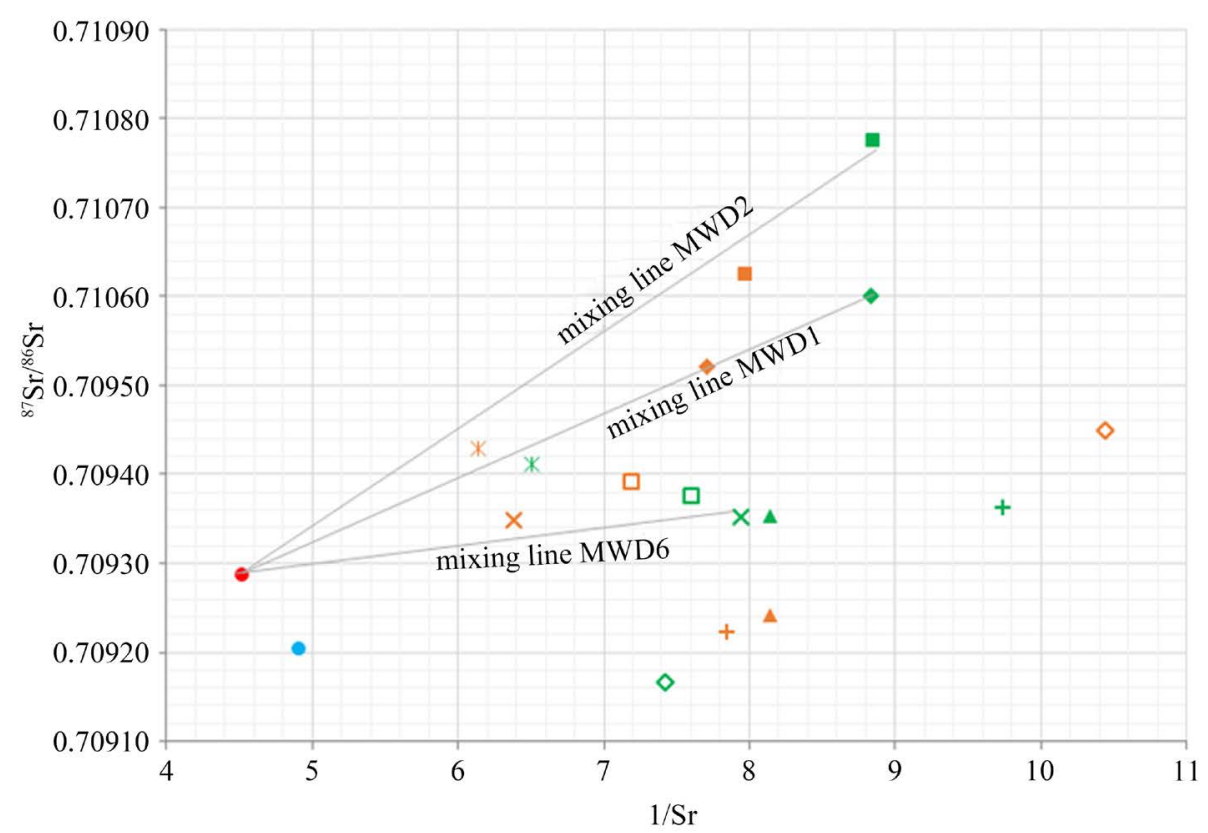

$\bullet$ MWD1 before injection =MWD2 before injection ※MWD3 before injection $\triangle M W D 4$ before injection +MWD5 before injection XMWD6 before injection 口MWD7 before injection $\diamond \mathrm{MWD} 8$ before injection $\diamond$ MWD1 after injection =MWD2 after injection ※MWD3 after injection AMWD4 after injection +MWD5 after injection XMWD6 after injection $\square$ MWD7 after injection $\diamond$ MWD8 after injection

\section{- Yom River}

-injected water

Figure 4. Correlation between ${ }^{87} \mathrm{Sr} /{ }^{86} \mathrm{Sr}$ and $1 / \mathrm{Sr}$ of deep aquifer injected water sample. The hypothetical mixing line for binary mixing would have a linear trend connecting the end members.

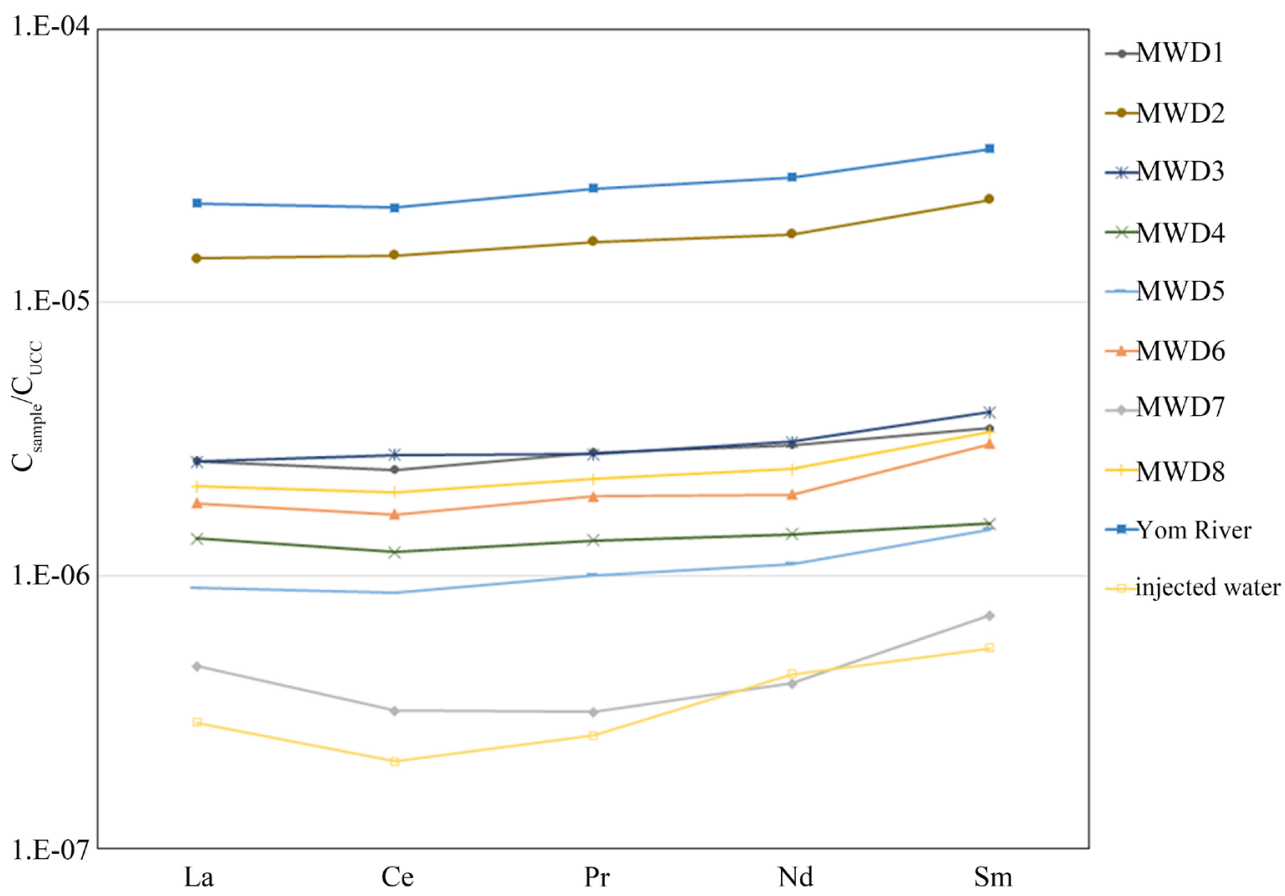

Figure 5. The UCC-normalized REE curve of deep aquifer groundwaters before injection, Yom River and injected water.

Furthermore, a systematic variation of the rare earth elements concentrations before and after injection has been observed. After injection, the REE concentrations of all deep aquifer groundwater samples have been increased. The rise of REE concentrations can be also used to estimate the amount of injected water in each monitoring wells. In this study, the concentrations of La were chosen as a tracer. Binary mixing is supposed between injected water and groundwater before injection as representing the end members. The results of the calculated mixtures are shown in Figure 6 and indicate the flow direction of injected water to be in southeastern. 


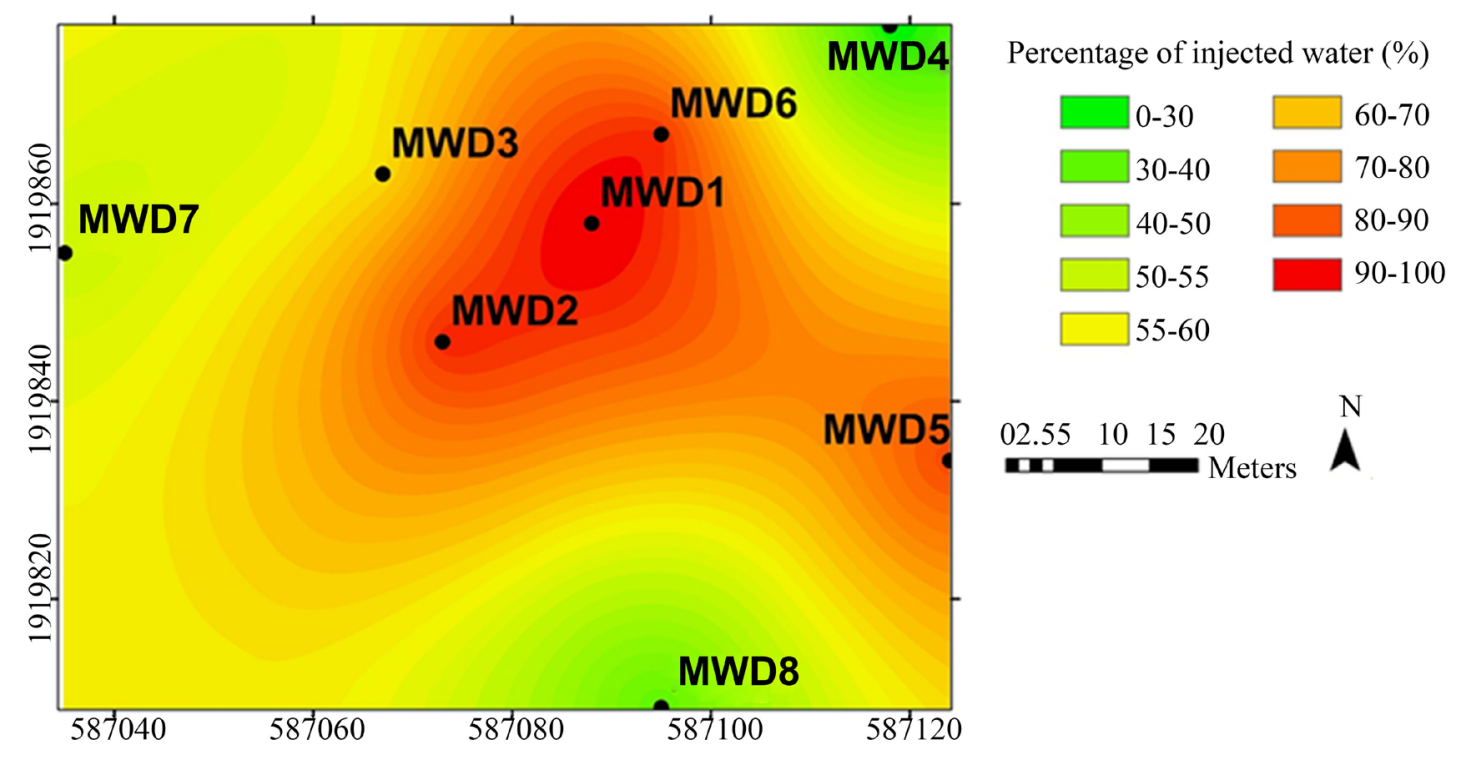

Figure 6. The flow direction of deep aquifer was constructed from the concentration of La.

\subsection{Long Term ASR Testing by Pump Pressure Method in Year 2013}

\subsubsection{Water Level}

1) Shallow Aquifer

The relationship between the water level of the recharge wells and the water level of the monitoring wells before injection, during injection and during extraction for shallow aquifer is shown in Figure 7. Before injection the water level of all wells are very close to each other. The statistic water level of the monitoring wells ranges from 47.03 - $47.12 \mathrm{~m}$ above Mean Sea Level (MSL). Treated water was injected into recharge well RWS2 with a recharge rate of $20-23 \mathrm{~m}^{3} / \mathrm{hr}$.

During injection water began to flow in every direction and headed in southwest-west and southeast-east direction. The water level of recharge wellRWS2 was elevated from 47.73 to $52.44 \mathrm{~m}$ (MSL) and the water levels of the monitoring wells (MWS1-MWS8) were drawn up $1.8-2.0 \mathrm{~m}$. After the injection was completed the injected water was stored in the aquifer for 17 days. After that water was extracted from the aquifer at the rate of $60-62 \mathrm{~m}^{3} / \mathrm{hr}$. The water levels in the monitoring wells during extraction are lower than the statistic water levels before injection by about $3 \mathrm{~m}$ and the water level of recharge well RWS2 is lower than that before injection by about $12 \mathrm{~m}$.

\section{2) Deep Aquifer}

The statistic water level of the monitoring wells (MWD1-MWSD) ranges from 45.77 - $45.85 \mathrm{~m}$ (MSL). By injection at the recharge rate of $16-19 \mathrm{~m}^{3} / \mathrm{hr}$ the water level of recharge well RWD2 was drawn up from 47.93 to $59.48 \mathrm{~m}$ (MSL) and the water levels of the monitoring wells (MWD1-MWD8) were drawn up $1.0-1.4 \mathrm{~m}$.

During injection water began to flow in every direction and headed in southeast direction. After injection the water was stored in the aquifer for 13 days to complete the homogenization between the injected water and the original groundwater in the aquifer. The groundwater was extracted from recharge well RWD2 at a rate of 55 $56 \mathrm{~m}^{3} / \mathrm{hr}$. Water levels in the monitoring wells are lower than the statistic water levels before injection by about $3 \mathrm{~m}$ and water level of RWD2 recharge well is lower than that before injection by about $8 \mathrm{~m}$.

\subsubsection{Strontium Isotopes}

$\mathrm{Sr}$ isotopic data are given in Appendix II. The ${ }^{87} \mathrm{Sr} /{ }^{86} \mathrm{Sr}$ ratios of all sampled water can be classified in four groups namely, monitoring wells of shallow aquifer (MWS1-MWS8), monitoring wells of deep aquifer (MWD1-MWD8), injected water and surface water. Surface waters from Yom River have high Sr content compared to the groundwater ranging between $0.176-0.202 \mu \mathrm{g} / \mathrm{g}$ and ${ }^{87} \mathrm{Sr} /{ }^{86} \mathrm{Sr}$ ratios ranging from 0.70934 to 0.70978. Sr content of injected water ranges from 0.126 to $0.173 \mu \mathrm{g} / \mathrm{g}$, whereas ${ }^{87} \mathrm{Sr} /{ }^{86} \mathrm{Sr}$ ratios varied little and ranges from 0.70951 to 0.70960 . 


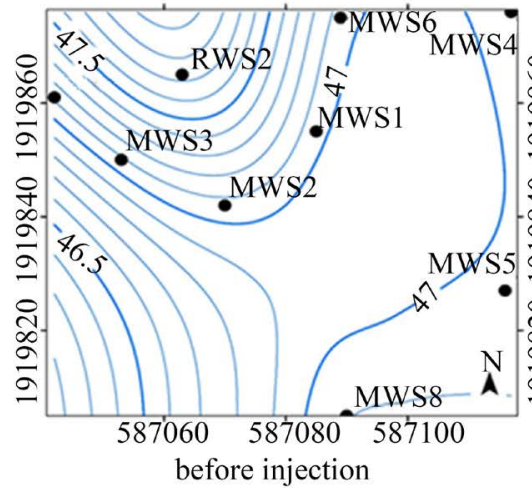

before injection

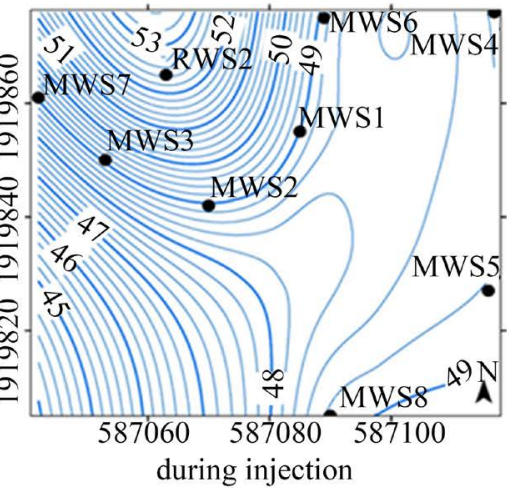

(a)
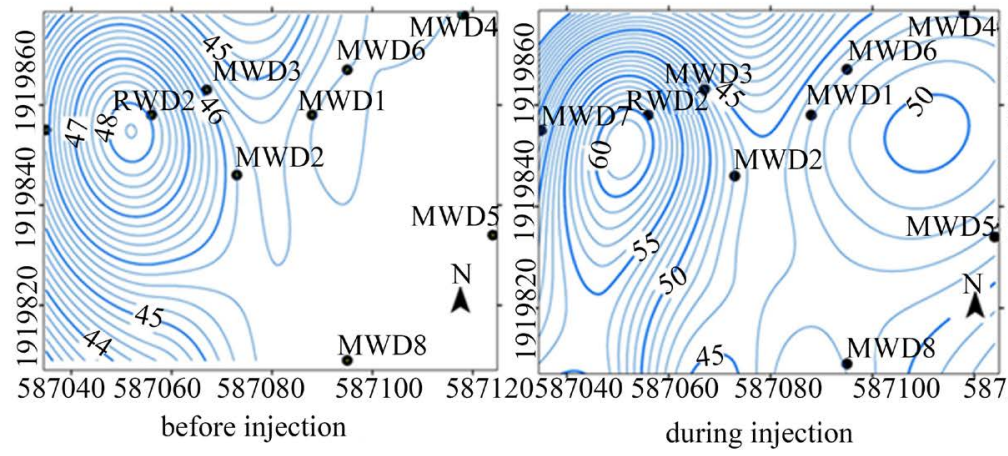
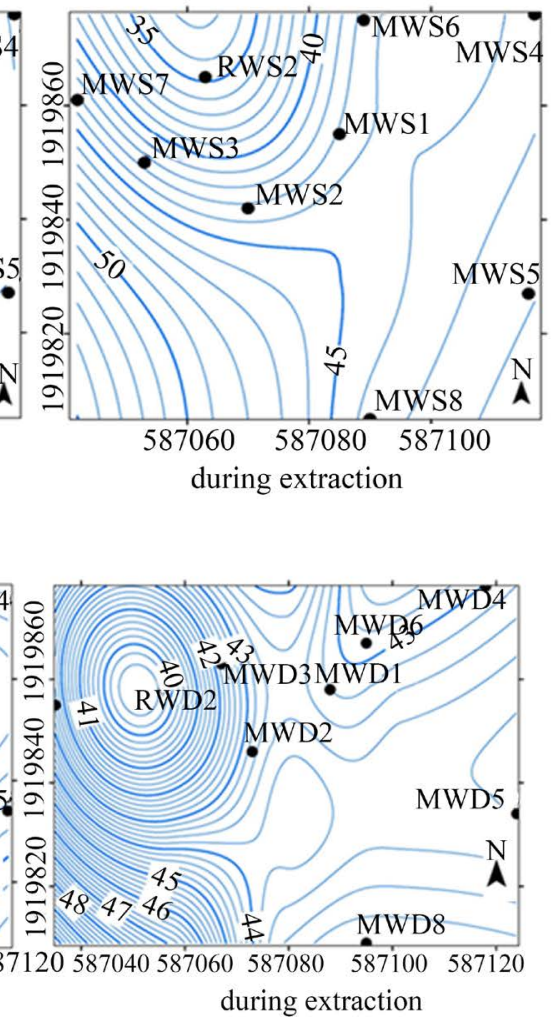

(b)

Figure 7. Water level in [m] above Mean Sea Level (MSL) before injection, during injection and during extraction of the shallow (a) and the deep aquifer (b).

\section{1) Shallow Aquifer}

Before injection, the groundwater in the shallow aquifer can be clearly differentiated from the groundwater in the deep aquifer by distinct $\mathrm{Sr}$ isotopic compositions. The Shallow aquifer in this study case can be classified by low $\mathrm{Sr}$ content and high ${ }^{87} \mathrm{Sr} /{ }^{86} \mathrm{Sr}$ ratios. The $\mathrm{Sr}$ content and ${ }^{87} \mathrm{Sr} /{ }^{86} \mathrm{Sr}$ ratios before the injection ranged from 0.099 to $0.117 \mu \mathrm{g} / \mathrm{g}$ and 0.70967 to 0.71050 respectively. The variation in ${ }^{87} \mathrm{Sr} /{ }^{86} \mathrm{Sr}$ ratios of the shallow aquifer before injection, during injection, storage and during extraction were interpolated by ArcGIS program as shown in Figure 8 and Figure 9. Before injection, the groundwater in this aquifer had relatively high ${ }^{87} \mathrm{Sr}{ }^{86} \mathrm{Sr}$ ratios compared to the injected water, which had mean the ${ }^{87} \mathrm{Sr} /{ }^{86} \mathrm{Sr}$ ratio of 0.70956 . Figure 8 shows the dispersion of injected water during injection and storage period. The result shows that the down gradient monitoring well MWS3 is the most affected by the injected water that flowed outward in the southwestern direction. The ${ }^{87} \mathrm{Sr} /{ }^{86} \mathrm{Sr}$ ratios were close to that of the injected water. Whereas the ${ }^{87} \mathrm{Sr} /{ }^{86} \mathrm{Sr}$ ratios in the monitoring wells farther away from the recharge well were relatively constant with standard deviation of $\pm 7 * 10^{-5}, \pm 9^{*} 10^{-6}$ and $\pm 2 * 10^{-5}$ for the monitoring wells MWS4, MWS5and MWS8, respectively.

\section{2) Deep Aquifer}

The deep aquifer can be classified by high $\mathrm{Sr}$ content and $\mathrm{low}^{87} \mathrm{Sr} /{ }^{86} \mathrm{Sr}$ ratios, which ranged from 0.107 to $0.134 \mu \mathrm{g} / \mathrm{g}$ and 0.70923 to 0.70965 respectively. The variation in ${ }^{87} \mathrm{Sr} /{ }^{86} \mathrm{Sr}$ ratios for the deep aquifer before injection, during injection, storage and during extraction are shown in Figure 9. Before injection, groundwater in this aquifer had relative low ${ }^{87} \mathrm{Sr}{ }^{86} \mathrm{Sr}$ ratios compared to the injected water, which had the mean ${ }^{87} \mathrm{Sr} /{ }^{86} \mathrm{Sr}$ ratio of 0.70956. Figure 9 shows the dispersion of the injected water during injection and storage period. The result shows that the injected water started with omnidirectional flow, reached MWD3 before entering MWD6 and headed in the southern and southwestern directions. The change of ${ }^{87} \mathrm{Sr} /{ }^{86} \mathrm{Sr}$ ratios in MWD4, MWD5 and MWD8 is insignificant and can be considered as constant values. This means that the injected groundwater did not reach the outside wells. After extraction, the ${ }^{87} \mathrm{Sr} /{ }^{86} \mathrm{Sr}$ ratios seemed to return to the original values before injection. 

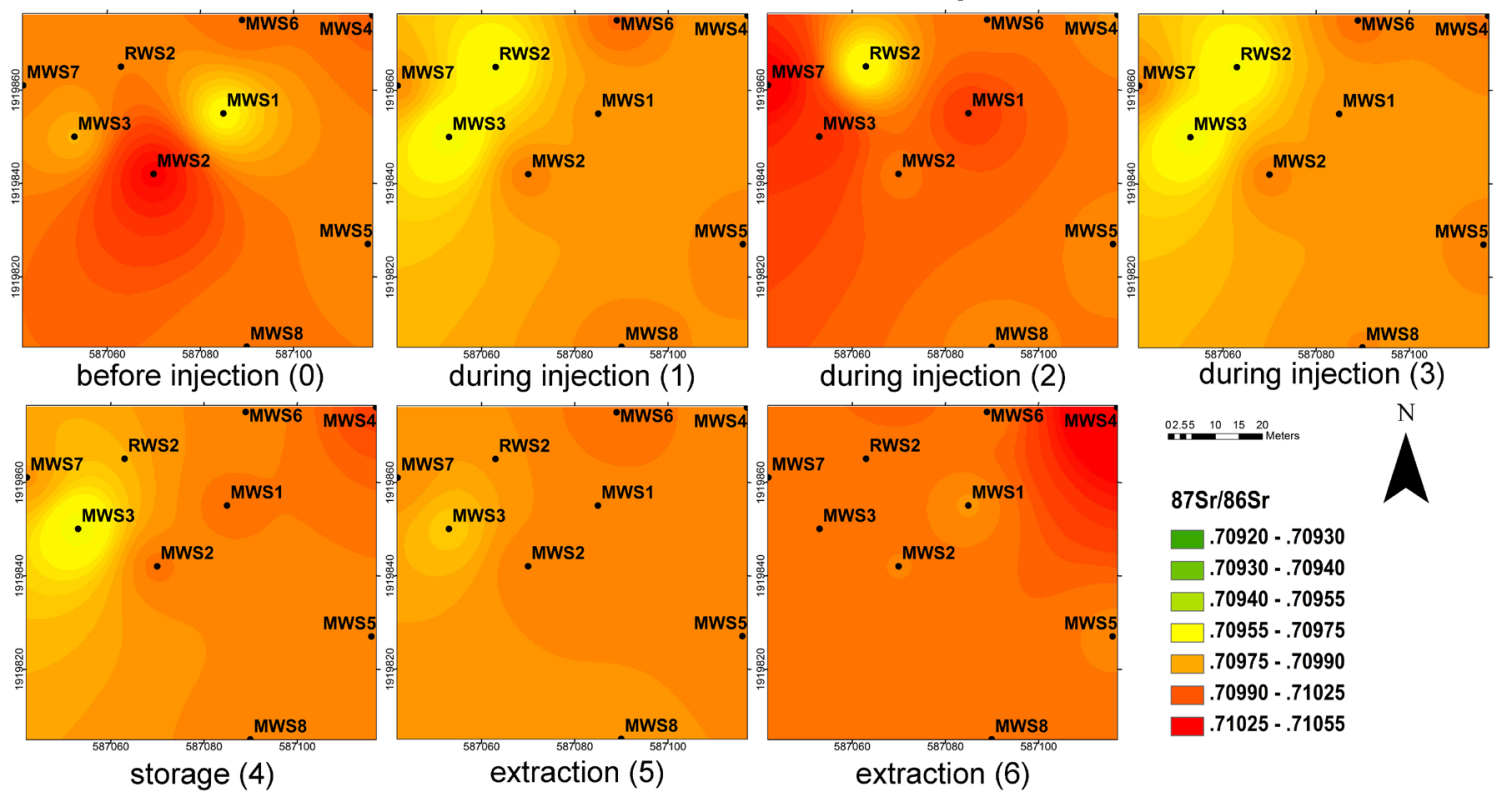

Figure 8. The variation in ${ }^{87} \mathrm{Sr} /{ }^{86} \mathrm{Sr}$ ratios of the shallow aquifer before injection, during injection, storage and during extraction.

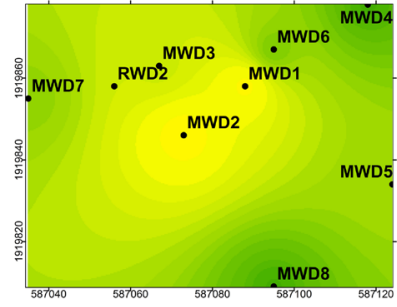

before injection $(0)$

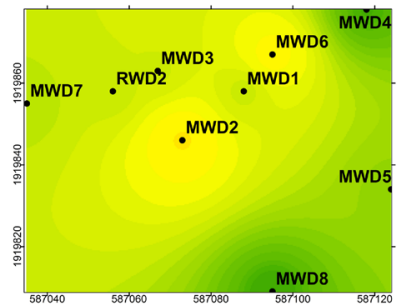

storage (4)

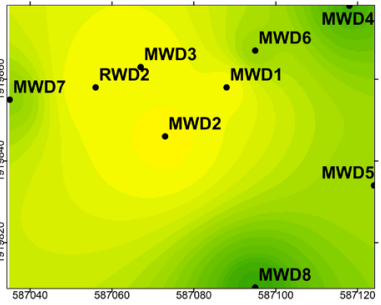

during injection (1)

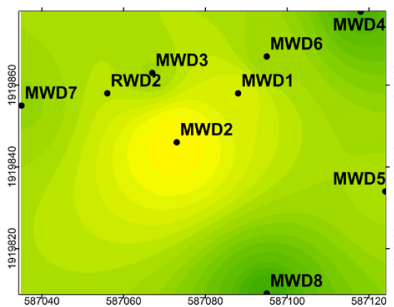

extraction (5)

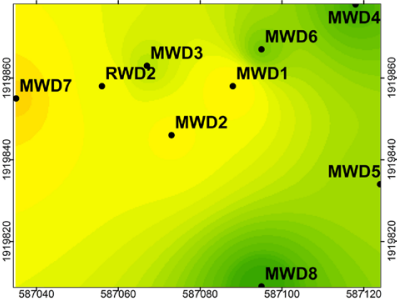

during injection (2)

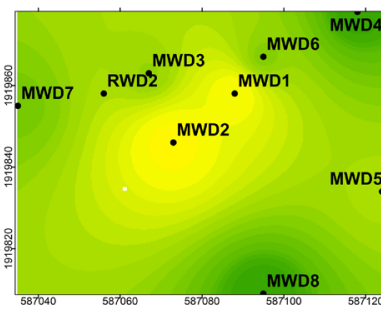

extraction (6)

Figure 9. The variation in ${ }^{87} \mathrm{Sr} /{ }^{86} \mathrm{Sr}$ ratios of the shallow aquifer before injection, during injection, storage and during extraction.

\subsubsection{Anions}

Concentrations of Anions $\left(\mathrm{Br}, \mathrm{Cl}, \mathrm{F}, \mathrm{NO}_{3}, \mathrm{PO}_{4}\right.$ and $\left.\mathrm{SO}_{4}\right)$ of the groundwater from the shallow and deep aquifer monitoring wells, injected water and surface water (Yom River) are summarized in Appendix II. $\mathrm{Br}$ and $\mathrm{PO}_{4}$ concentrations in most water samples are below detection limit. $\mathrm{F}$ and $\mathrm{NO}_{3}$ concentrations in the shallow and in the deep aquifer are lower than 0.7 and $3.3 \mathrm{ppm}$, respectively. $\mathrm{SO}_{4}$ concentration ranges from 3.3 to $27.9 \mathrm{ppm}$. $\mathrm{Cl}$ concentrations in injected water $(18-23 \mathrm{ppm})$ were significantly higher than those in the deep and shallow aquifers (4-13 ppm). The high difference in $\mathrm{Cl}$ concentration between the injected water and the groundwater in the aquifer can be used to trace the flow of injected water as shown in Figure 10 and Figure 11. 

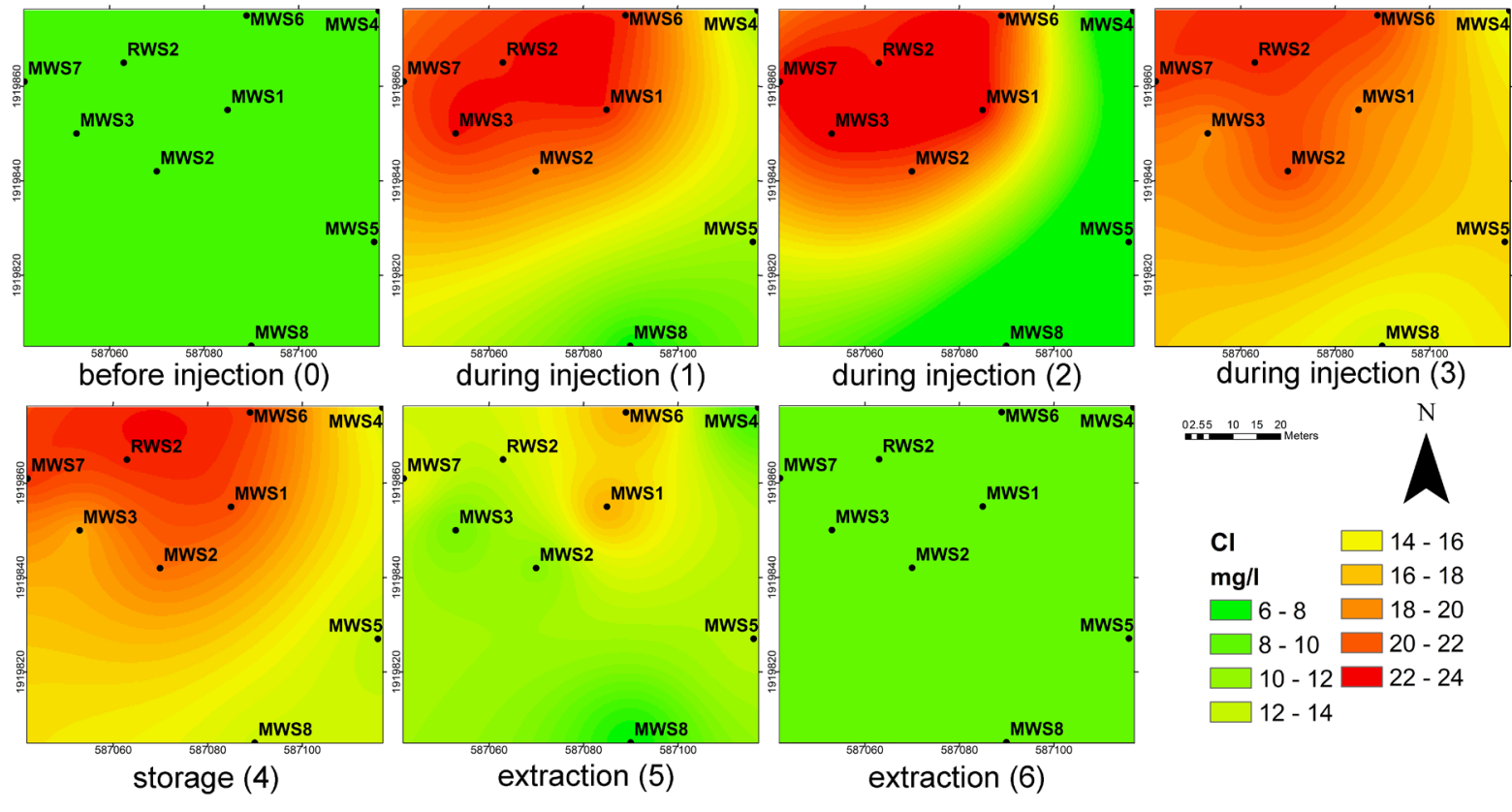

during injection (2)

during injection (3)
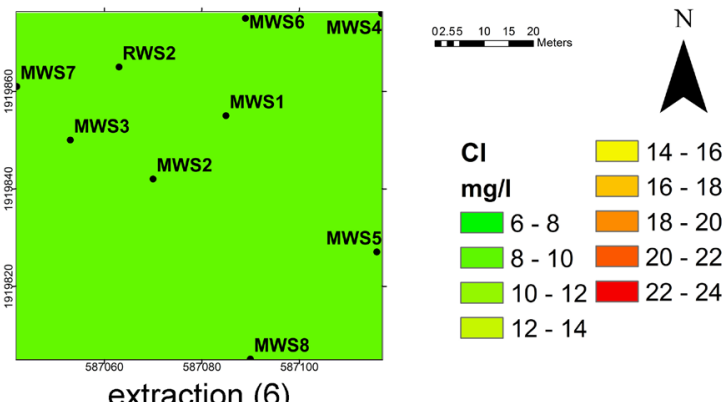

Figure 10. The change in $\mathrm{Cl}$ concentration of shallow aquifer before injection, during injection, storage and extraction.

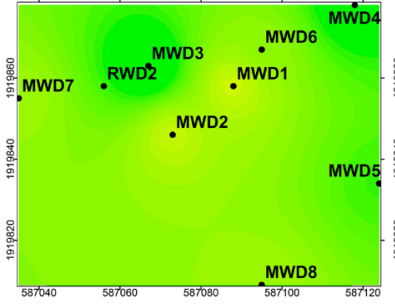

before injection (0)

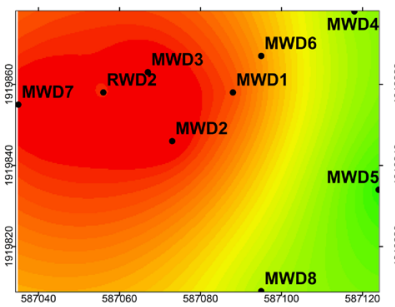

storage (4)

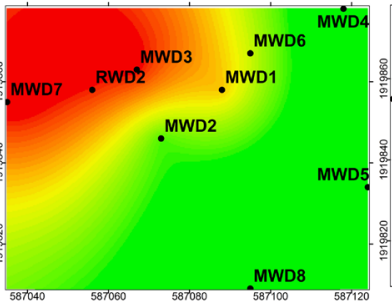

during injection (1)

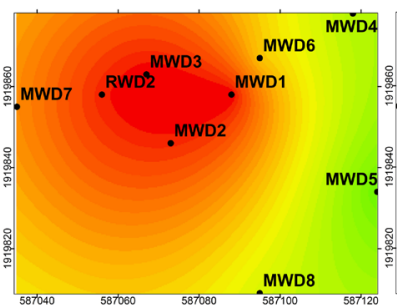

extraction (5)

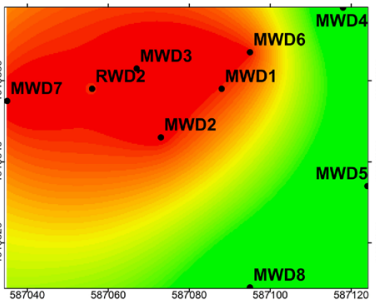

during injection (2)

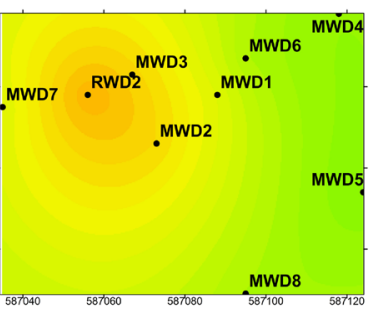

extraction (6)

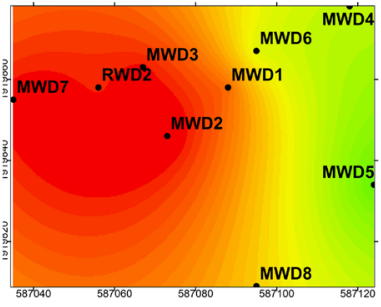

during injection (3)

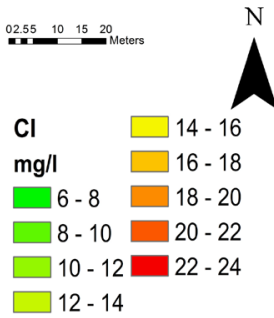

Figure 11. The change in $\mathrm{Cl}$ concentration of deep aquifer before injection, during injection, storage and extraction.

\section{1) Shallow Aquifer}

In the shallow aquifer the injected water started moving with omnidirectional flow, it reached the closest downgradient monitoring wells MWD3 and MWD1 before entering MWD7, MWD6 and MWD2 as shown in Figure 10. Only a small amount of $\mathrm{Cl}$ could be detected in MWD4, MWD5 and MWD8. Thereafter the groundwater flowed in a south-southwestern direction in accordance with the regional flow direction. During extraction the $\mathrm{Cl}$ concentrations have gradually decreased. The extraction was preferentially performed from the downgradient wells and the injected water could be completely extracted from the shallow aquifer. After extraction, the $\mathrm{Cl}$ concentration seemed to return to the original values before injection.

\section{2) Deep Aquifer}


Figure 11 shows that the injected water started with omnidirectional flow, reached the closest monitoring wells MWD3 and MWD7 before entering MWD2 and MWD6. The injected water flowed in east-later in southwestern direction. Only a small amount of $\mathrm{Cl}$ could be detected in MWD4 and MWD8. Whereas the change in the $\mathrm{Cl}$ concentration in the distant downgradient wells MWD5 was insignificant. This means that the injected water reached the downgradient monitoring wells MWD5 and MWD8 only in small amounts. During extraction the $\mathrm{Cl}$ concentrations have gradually decreased. Nevertheless, the extraction was not completed as planned because $\mathrm{Cl}$ could still be found in some wells.

\subsubsection{Stable Isotopes $\left(\delta \mathrm{D}\right.$ and $\left.\delta^{18} 0\right)$}

The variation of stable isotopes ( $\delta \mathrm{D}$ and $\left.\delta^{18} \mathrm{O}\right)$ are summarized in Appendix II. The $\delta \mathrm{D}$ and $\delta^{18} \mathrm{O}$ values in the injected water ranges between $-48 \%$ to $-38 \%$ and -6.5 to -4.5 , respectively. The $\delta \mathrm{D}$ and $\delta^{18} \mathrm{O}$ in injected water during the beginning of injection was more enriched than that by the later injection. This could be the result of evaporation effect, which could have happened during the long storage period in the storage tank before injection.

\section{1) Shallow Aquifer}

Figure 12 shows that the $\delta \mathrm{D}$ and $\delta^{18} \mathrm{O}$ are enriched in the first event and gradually become depleted from event 2 to event 6 . The succession of $\delta \mathrm{D}$ and $\delta^{18} \mathrm{O}$ for the first event during injection is MWS6 $>$ MWS1, MWS7 $>$ MWS3, MWS5, MWS2, MWS8 $>$ MWS4. In event 3 the succession of $\delta \mathrm{D}$ and $\delta^{18} \mathrm{O}$ has changed as follow MWS1 > MWS3, MWS2 > MWS6, MWS7, MWS8 > MWS4, MWS5. This means that during injection groundwater in the shallow aquifer started to flow in every direction because the close monitoring wells are more affected and then the water heads to the southwest direction. After extraction, the $\delta \mathrm{D}$ and $\delta^{18} \mathrm{O}$ changed values close to those of the native groundwater before injection.

\section{2) Deep Aquifer}

Figure 13 shows that the $\delta \mathrm{D}$ and $\delta^{18} \mathrm{O}$ are gradually enriched in the first event and reach the most enriched value in the second event. Then the value becomes more depleted from event 3 to event 6 . The succession of $\delta \mathrm{D}$ and $\delta^{18} \mathrm{O}$ for the second event during injection is MWD7 > MWD3 > MWD2 > MWD4, MWD6, MWD8 > MWD5. The monitoring wells, which are close to the RWD2 recharge well (MWD7, MWD3, MWD2), are most affected. Whereas the change of $\delta \mathrm{D}$ and $\delta^{18} \mathrm{O}$ in other wells is insignificant.

\subsubsection{Rare Earth Elements (REE)}

REE concentrations of shallow and deep aquifer monitoring wells are summarized in Appendix III. REE concentrations of injected water varied strongly within the time of investigation. The change in the concentrations of the Yom River seems to vary strongly as an effect of meteoric waters draining into the river. This is shown in Figure 14 for the Ce-concentration representing the most abundant element. The Ce concentration increased after heavy rainfall. Therefore, it is not possible to model the movement of water based on REE concentrations as it was for Sr-isotopes.

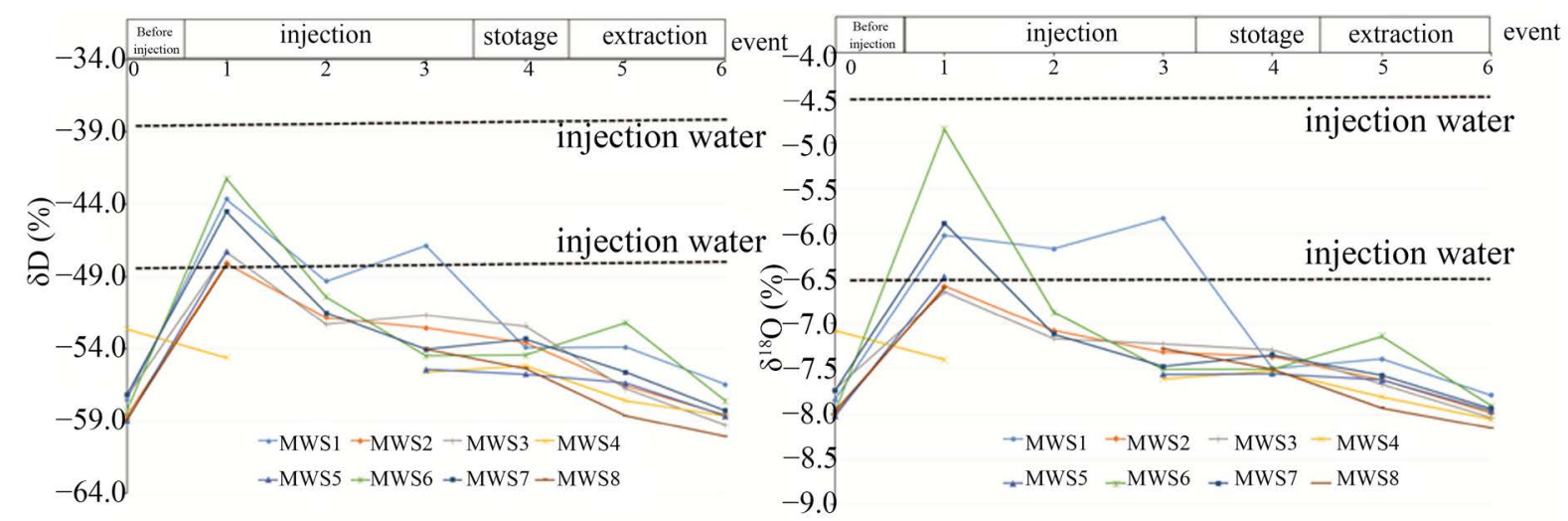

Figure 12. The variation of stable isotopes $\left(\delta \mathrm{D}\right.$ and $\left.\delta^{18} \mathrm{O}\right)$ in shallow aquifer before injection, during injection, storage and extraction. 

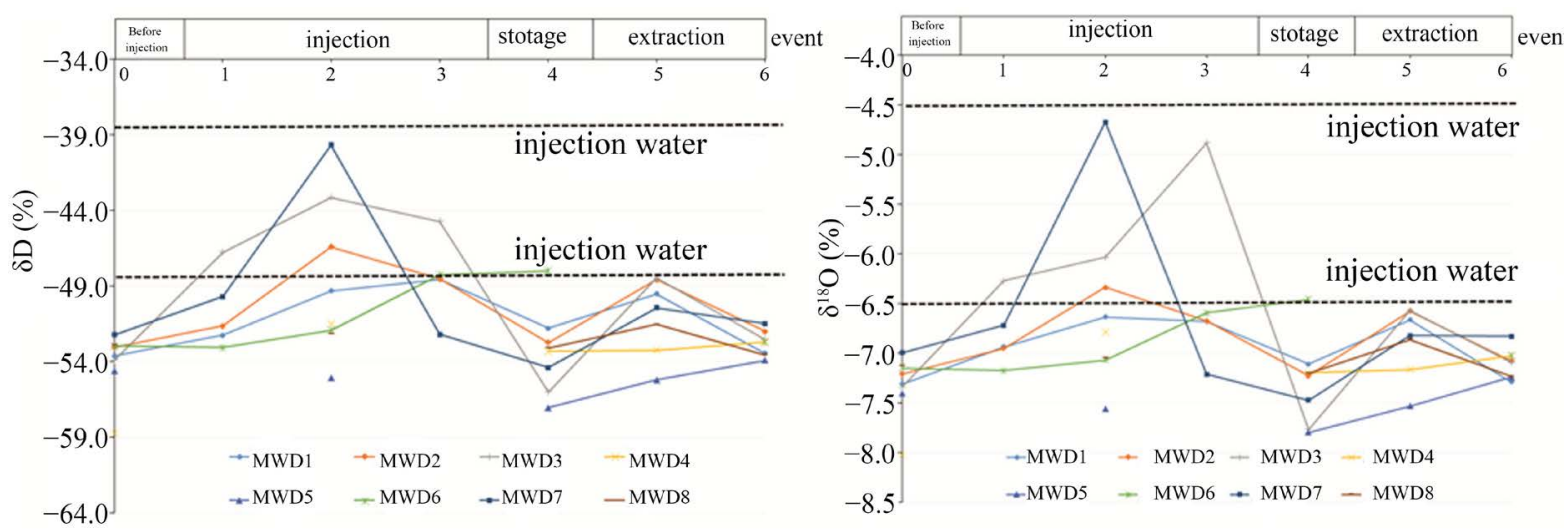

Figure 13. The variation of stable isotopes $\left(\delta \mathrm{D}\right.$ and $\left.\delta^{18} \mathrm{O}\right)$ in deep aquifer before injection, during injection, storage and extraction.

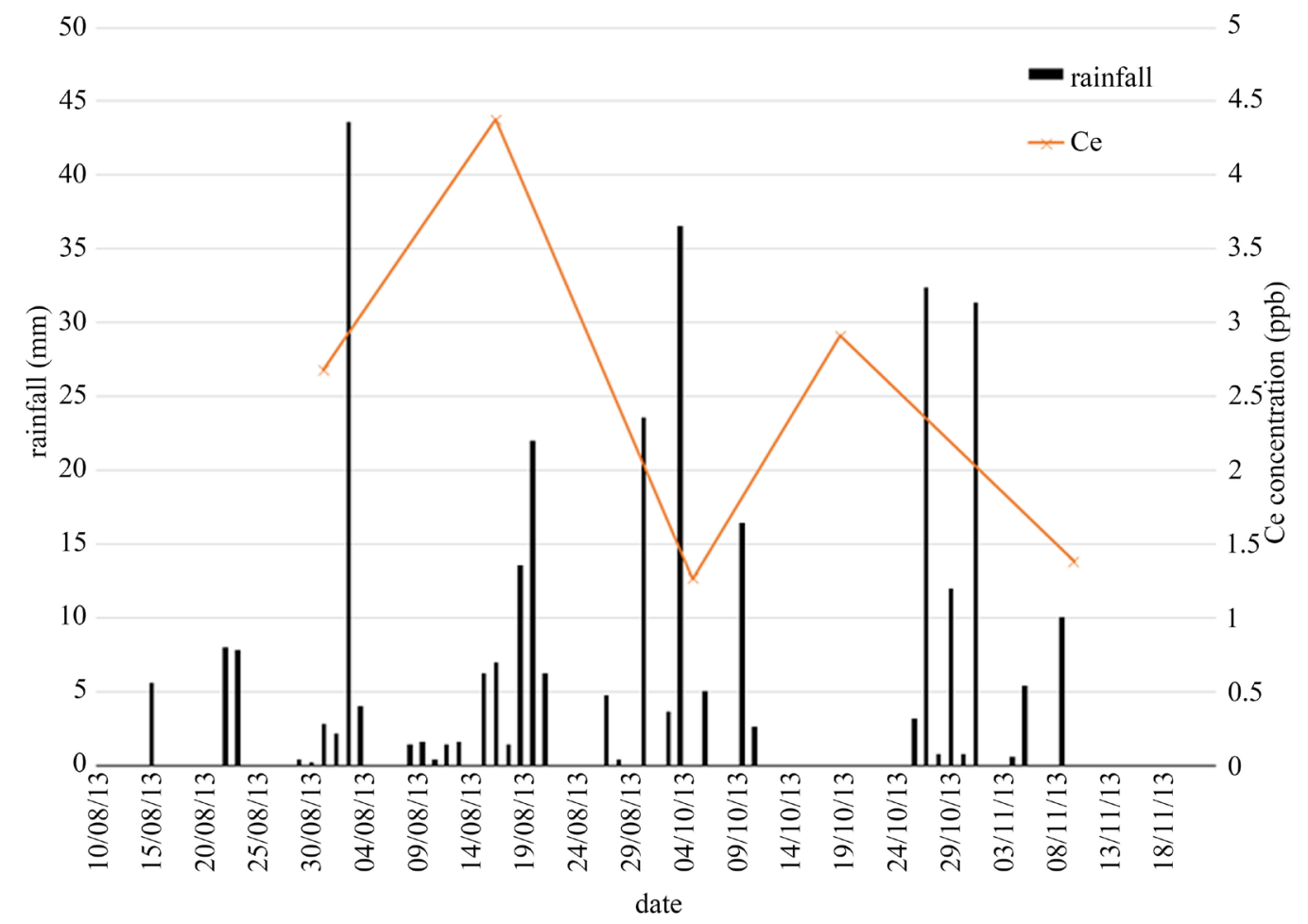

Figure 14. Influence of rainfall on the concentration of Ce in the Yom River.

\section{Discussion}

In this study Strontium isotopic ratio $\left({ }^{87} \mathrm{Sr} /{ }^{86} \mathrm{Sr}\right)$, stable isotopes $\left(\delta \mathrm{D}\right.$ and $\left.\delta^{18} \mathrm{O}\right)$, chloride concentration and REE concentration were used to trace the flow path during injection and extraction within ASR project to prove the suitability of natural tracers and to evaluate the achievement of this project. Results from all tracers show a similar trend of the flow path with omnidirectional flow at the beginning of injection and then headed to the southwestern direction in accordance with the regional flow direction. Only the result of La concentration by initial long term ASR testing in year 2012 show the flow in southeastern direction. Obvious variations can be found in the monitoring wells close to the recharge wells (MWS1, MWS2, MWS3, MWS6, MWS7, MWD1, MWD2, MWD3, MWD6, MWD7). Only small variations can be found in the monitoring well farther away from the recharge wells (MWS4, MWS5, MWS8, MWD4, MWD5, MWD8). The results from the tracers also show that the efficiency for recharge and extraction of the shallow aquifer is better than the deep aquifers. 
Strontium is an appropriate tracer because it occurs naturally and is neither affected by geological processes nor fractionation [4]. For this study, the shallow aquifer can be distinguished from the deep aquifer due to the difference of concentrations of $\mathrm{Sr}$ and ${ }^{87} \mathrm{Sr} /{ }^{86} \mathrm{Sr}$ ratios. The ${ }^{87} \mathrm{Sr} /{ }^{86} \mathrm{Sr}$ ratio variations within a hydrogeological system can provide information about the source of $\mathrm{Sr}$ and the mixing processes [14] [15]. The variations of ${ }^{87} \mathrm{Sr} /{ }^{86} \mathrm{Sr}$ ratios can be observed, especially for the monitoring wells, which are close to the recharge well either in the shallow or in the deep aquifer. An important thing that must be taken into account is the difference in values of ${ }^{87} \mathrm{Sr}{ }^{86} \mathrm{Sr}$ ratios between the injected water and the native groundwater in the aquifer. Some results of the groundwater samples are different from the injected water by the fifth decimal place only. Therefore, it is not easy to distinguish, if those values are the result of mixing or not. Stable isotopes ( $\delta \mathrm{D}$ and $\delta^{18} \mathrm{O}$ ) can be usually used to characterize groundwater from different sources. The problem for this study is the inconsistence of the $\delta \mathrm{D}$ and $\delta^{18} \mathrm{O}$ composition in the injected water due to fractionation that occurs during evaporation and it is not easy to control the constant values of $\delta \mathrm{D}$ and $\delta^{18} \mathrm{O}$ in injected water. Consequently, $\delta \mathrm{D}$ and $\delta^{18} \mathrm{O}$ are not the suitable tracers for this study case. $\mathrm{Cl}$ concentration was also used as a tracer in this project because of the concentration difference in injected water and native groundwater. $\mathrm{Cl}$ concentration in treated water are $2-5$ times higher than that in the groundwater and can be considered as a suitable tracer for this project.

Moreover, it is obvious that opposite to the behavior of REE in brines where the concentrations stayed nearly constant over years [16], the present groundwater samples varied strongly within the time of investigation. The change in the concentrations of the Yom River seems to vary strongly as an effect of meteoric waters draining into the river. Nevertheless, there is a big difference in the REE concentrations between the Yom River water and the injected water. This is related to the fact that the river water before injection is treated with polyaluminum chloride to avoid the formation of colloids, which might clock the injection. These colloids are precipitated in the clarifier tank before injection.

The injected water changes in concentration with respect to the REE during injection and storage as further complex fractions due to reaction with organic matter is produced in the aquifer, therefore it is not possible to model the movement of water as it was for Sr-isotopes.

Nevertheless, the flow path of groundwater in this project cannot be clearly interpreted because of the limited number of monitoring wells, small distance between each monitoring well and short duration of injection.

\section{Conclusions}

ASR is one of the alternative technologies that could be applied for solving the drought problem in dry seasons for certain application such as agriculture, consumption and industrial uses. To assess the efficiency of the ASR process, some tracers are required. In this case, the concentration of $\mathrm{Cl}$ in injected water is higher than the native groundwater in the aquifer, due to the addition of $\mathrm{NaOCl}$ for disinfection purposes during the treatment of surface water before injection. Therefore, $\mathrm{Cl}$ concentration can be used as an appropriate tracer to track the process during the artificial recharge. However, for a long-term study the ${ }^{87} \mathrm{Sr}{ }^{86} \mathrm{Sr}$ ratios should be a more suitable tracer, because of their precision. Strontium isotopes are sensitive indicators. Although the changes of ${ }^{87} \mathrm{Sr} /{ }^{86} \mathrm{Sr}$ ratios in some water samples are small, they are significant. Small amount of contaminants can be already detected by changing the ${ }^{87} \mathrm{Sr} /{ }^{86} \mathrm{Sr}$ ratios. They are not affected by fractionation or mineral precipitation. The isotopic fingerprints of groundwater and surface water can be easily used to track the artificial recharge process, especially when the difference in ${ }^{87} \mathrm{Sr} /{ }^{86} \mathrm{Sr}$ ratios of the injected water and native groundwater is significant. The isotopic changes of groundwater in the aquifer resulting from injected water can be traced.

The tracer characteristic of $\mathrm{Sr}$ isotopes should be useful for the government to manage groundwater exploitation and groundwater conservation for sustainable use, such as to track the sea water intrusion into the aquifers or to track the illegal groundwater abstraction, which are serious problems nowadays.

\section{Acknowledgements}

The authors thank the staffs of SNT consultants and staffs of the Department of Groundwater Resources for fieldwork support during sampling and academic discussion as well as the staffs of Thailand institute of Nuclear Technology for technical support by sample analyses. We thank financial support from the Open Access Publication Fund of Göttingen University. M.H. appreciates the advice and help in the laboratory by Klaus Wemmer, Nicole Nolte, Franziska Wilski and Brigitte Dietrich (all GZG, Göttingen). 


\section{References}

[1] Department of Groundwater Resources (2011) Pilot Study and Experiment on Managed Aquifer Recharge Using Ponding System in the Lower North Region River Basin, Pitsanulok, Sukhothai and Pichit Provinces. Final Report, Bangkok, Thailand, 420 p. (In Thai)

[2] Department of Groundwater Resources (2015) Exploring Corrective Means for Solving Flood and Drought Problem by ASR Method in the Northern Part of Chao Phraya River Basin. Final Report, Bangkok, Thailand. (In Thai)

[3] Phien-wej, N., Giao, P.H. and Nutalaya, P. (1998) Field Experiment of Artificial Recharge through a Well with Reference to Land Subsidence Control. Engineering Geology, 50, 187-201. http://dx.doi.org/10.1016/S0013-7952(98)00016-7

[4] Klaus, J.S., Hansen, B.T. and Buapeng, S. (2007) ${ }^{87} \mathrm{Sr} /{ }^{86} \mathrm{Sr}$-Ratios: A Natural Tracer to Characterize the Groundwater of Bangkok Area, Thailand, with Respect to Public Water Supply and Freshwater Reinjection. Hydrogeology Journal, 15, 745-758. http://dx.doi.org/10.1007/s10040-007-0175-Z

[5] Land, M., Ingri, J., Andersson, P.S. and Öhlander, B. (2000) $\mathrm{Ba} / \mathrm{Sr}, \mathrm{Ca} / \mathrm{Sr}$ and ${ }^{87} \mathrm{Sr} /{ }^{86} \mathrm{Sr}$ Ratios in Soil Water and Groundwater: Implication for Relative Contributions to Stream Water Discharge. Applied Geochemistry, 15, 311-325. http://dx.doi.org/10.1016/S0883-2927(99)00054-2

[6] Négrel, P. and Petelet-Giruad, E. (2005) Strontium Isotopes as Tracers of Groundwater Induced Floods: The Sommer Case Study (France). Journal of Hydrology, 305, 99-119. http://dx.doi.org/10.1016/j.jhydrol.2004.08.031

[7] Clark, I.D. (2015) Groundwater Geochemistry and Isotope. CRC Press, 438 p. http://dx.doi.org/10.1201/b18347

[8] Wiegand, B., Dietzel, M., Bielert, U., Groth, P. and Hansen, B.T. (2001) ${ }^{87} \mathrm{Sr} /{ }^{86} \mathrm{Sr}-$ Verhältnisse als Tracer für hydrochemische Prozesse in einem Lockergesteinsaquifer (Libenau, NW-Deutschland). Acta Hydrochimica et Hydrobiologica, 29, 139-152. http://dx.doi.org/10.1002/1521-401X(200109)29:2/3<139::AID-AHEH139>3.0.CO;2-Z

[9] Faure, G. and Mensing, T.M. (2005) Isotope Principle and Applications. 3rd Edition, John Wiley \& Sons, Hoboken.

[10] Schmidt, R.A., Smith, R.H., Lasch, J.A., Olehy, A.W.A. and Vasilevshis, J. (1963) Abundances of Fourteen RareEarth Elements, Scandium, and Yttrium in Meteoritic and Terrigenous Matter. Geochimica et Cosmochi-Mica Acta, 27, 577-622. http://dx.doi.org/10.1016/0016-7037(63)90014-0

[11] Wildman, T.R. and Haskin, L. (1965) Rare-Earth Elements in Ocean Sediments. Journal of Geophysical Research, 70, 2905-2911. http://dx.doi.org/10.1029/JZ070i012p02905

[12] Mason, B. (1966) Principals of Geochemistry. John Wiley \& Sons, New York.

[13] Piper, D. and Bau, M. (2013) Normalized Rare Earth Elements in Water, Sediments, and Wine: Identifying Sources and Environmental Redox Conditions. American Journal of Analytical Chemistry, 4, 69-83. http://dx.doi.org/10.4236/ajac.2013.410A1009

[14] Négrel, P., Fouillac, C. and Brach, M. (1997) A Strontium Isotopic Study of Mineral and Surface Waters from the Cézallier (Massif Central, France): Implications for Mixing Processes in Areas of Disseminated Emergences of Mineral Water. Chemical Geology, 135, 89-101. http://dx.doi.org/10.1016/s0009-2541(96)00110-6

[15] Négrel, P., Cassanova, J. and Aranyossy, J.F. (2001) Strontium Isotope Systematics Use to Decipher the Origin of Groundwaters Sampled from Granitoids: The Vienne Case (France). Chemical Geology, 177, 287-308. http://dx.doi.org/10.1016/S0009-2541(00)00414-9

[16] Möller, P., Woith, H., Dulski, P., Lüders, V., Erzinger, J., Kämpf, H., Pekdeger, A., Hansen, B.T., Lodemann, M. and Banks, D. (2005) Main and Trace Elements in the KTB-VB Fluid: Composition and Hints to Its Origin. Geofluids, 5, 28-41. http://dx.doi.org/10.1111/j.1468-8123.2004.00104.x 
Appendix

\begin{tabular}{|c|c|c|c|c|c|c|c|c|c|c|}
\hline sample name & sampling date & ${ }^{87} \mathrm{Sr} /{ }^{86} \mathrm{Sr}$ & 2 se & $\operatorname{Sr}(\mu \mathrm{g} / \mathrm{g})$ & $1 / \mathrm{Sr}$ & La (ppb) & $\mathrm{Ce}$ (ppb) & $\operatorname{Pr}(p p b)$ & Nd (ppb) & Sm (ppb) \\
\hline MWS 1 & 16.10 .2012 & 0.70998 & 0.00096 & 0.094 & 10.6 & 0.039 & 0.081 & 0.010 & 0.037 & 0.008 \\
\hline MWS 2 & 16.10 .2012 & 0.71000 & 0.00069 & 0.104 & 9.6 & 0.062 & 0.122 & 0.014 & 0.056 & 0.011 \\
\hline MWS 3 & 16.10 .2012 & 0.71050 & 0.00214 & 0.109 & 9.2 & 0.027 & 0.054 & 0.006 & 0.022 & 0.006 \\
\hline MWS 4 & 16.10 .2012 & 0.70994 & 0.00045 & 0.101 & 9.9 & 0.045 & 0.094 & 0.012 & 0.048 & 0.013 \\
\hline MWS 5 & 16.10 .2012 & 0.70996 & 0.00035 & 0.105 & 9.5 & 0.037 & 0.066 & 0.009 & 0.028 & 0.006 \\
\hline MWS 6 & 16.10 .2012 & 0.70999 & 0.00107 & 0.108 & 9.2 & 2.284 & 4.745 & 0.604 & 2.378 & 0.515 \\
\hline MWS 7 & 16.10 .2012 & 0.70998 & 0.00070 & 0.109 & 9.2 & 0.042 & 0.074 & 0.010 & 0.039 & 0.008 \\
\hline MWS 8 & 16.10 .2012 & 0.71001 & 0.00194 & 0.103 & 9.7 & 0.033 & 0.073 & 0.008 & 0.035 & 0.007 \\
\hline MWD 1 & 16.10 .2012 & 0.70960 & 0.00057 & 0.113 & 8.8 & 0.079 & 0.157 & 0.020 & 0.079 & 0.016 \\
\hline MWD 2 & 16.10 .2012 & 0.70977 & 0.00219 & 0.113 & 8.9 & 0.437 & 0.956 & 0.119 & 0.463 & 0.108 \\
\hline MWD 3 & 16.10 .2012 & 0.70941 & 0.00098 & 0.154 & 6.5 & 0.079 & 0.177 & 0.020 & 0.081 & 0.018 \\
\hline MWD 4 & 16.10 .2012 & 0.70935 & 0.00214 & 0.123 & 8.1 & 0.079 & 0.177 & 0.020 & 0.081 & 0.018 \\
\hline MWD 5 & 16.10 .2012 & 0.70936 & 0.00094 & 0.103 & 9.7 & 0.027 & 0.055 & 0.007 & 0.029 & 0.007 \\
\hline MWD 6 & 16.10 .2012 & 0.70935 & 0.00284 & 0.126 & 7.9 & 0.055 & 0.108 & 0.014 & 0.052 & 0.014 \\
\hline MWD 7 & 16.10 .2012 & 0.70938 & 0.00043 & 0.132 & 7.6 & 0.014 & 0.021 & 0.002 & 0.011 & 0.003 \\
\hline MWD 8 & 16.10 .2012 & 0.70917 & 0.00069 & 0.135 & 7.4 & 0.064 & 0.130 & 0.016 & 0.064 & 0.015 \\
\hline MWD 1 & 17.11 .2012 & 0.70952 & 0.00091 & 0.130 & 7.7 & 0.008 & 0.010 & 0.001 & 0.005 & 0.002 \\
\hline MWD 2 & 17.11 .2012 & 0.70962 & 0.00041 & 0.125 & 8.0 & 0.024 & 0.040 & 0.004 & 0.015 & 0.004 \\
\hline MWD 3 & 17.11.2012 & 0.70943 & 0.00015 & 0.163 & 6.1 & 0.030 & 0.039 & 0.002 & 0.009 & 0.003 \\
\hline MWD 4 & 17.11 .2012 & 0.70924 & 0.00165 & 0.123 & 8.1 & 0.031 & 0.056 & 0.005 & 0.018 & 0.006 \\
\hline MWD 5 & 17.11.2012 & 0.70922 & 0.00027 & 0.127 & 7.8 & 0.010 & 0.015 & 0.002 & 0.005 & 0.002 \\
\hline MWD 6 & 17.11.2012 & 0.70935 & 0.00085 & 0.157 & 6.4 & 0.011 & 0.015 & 0.002 & 0.007 & 0.002 \\
\hline MWD 7 & 17.11 .2012 & 0.70939 & 0.00083 & 0.139 & 7.2 & 0.011 & 0.013 & 0.001 & 0.005 & 0.002 \\
\hline MWD 8 & 17.11 .2012 & 0.70945 & 0.00070 & 0.096 & 10.4 & 0.041 & 0.069 & 0.007 & 0.027 & 0.006 \\
\hline Yom river & 16.10 .2012 & 0.70943 & 0.00085 & 0.205 & 4.9 & 0.694 & 1.427 & 0.186 & 0.750 & 0.165 \\
\hline Yom River & 17.11 .2012 & 0.70920 & 0.00050 & 0.203 & 4.9 & 0.273 & 0.502 & 0.067 & 0.281 & 0.065 \\
\hline Injected Water & 16.10 .2012 & 0.70929 & 0.00055 & 0.221 & 4.5 & 0.009 & 0.013 & 0.002 & 0.011 & 0.002 \\
\hline
\end{tabular}

Appendix II. Sr-isotopic composition, $\delta^{18} \mathrm{O}, \delta \mathrm{D}$ and anion concentration of water samples from ASR long term testing in year 2013 .

\begin{tabular}{|c|c|c|c|c|c|c|c|c|c|c|c|c|}
\hline sample & event & ${ }^{87} \mathrm{Sr} /{ }^{86} \mathrm{Sr}$ & $2 \mathrm{se}$ & $\begin{array}{c}\mathrm{Sr} \\
(\mu \mathrm{g} / \mathrm{g})\end{array}$ & $\begin{array}{l}\delta^{18} O \\
(\%)\end{array}$ & $\underset{(\%)}{\Delta d}$ & $\begin{array}{c}\mathrm{Br} \\
(\mathrm{ppm})\end{array}$ & $\begin{array}{c}\mathrm{Cl} \\
(\mathrm{ppm})\end{array}$ & $\begin{array}{c}\text { F } \\
(p p m)\end{array}$ & $\begin{array}{c}\mathrm{NO}_{3} \\
(\mathrm{ppm})\end{array}$ & $\begin{array}{c}\mathrm{PO}_{4} \\
\text { (ppm) }\end{array}$ & $\begin{array}{c}\mathrm{SO}_{4} \\
(\mathrm{ppm})\end{array}$ \\
\hline \multirow{7}{*}{ MWS1 } & 0 & 0.70967 & 0.00007 & 0.102 & -7.8 & -57.5 & n.a. & 5.5 & 0.2 & 1.1 & n.a. & n.a. \\
\hline & 1 & 0.70993 & 0.00001 & 0.081 & -6.0 & -43.7 & n.a. & 22.9 & 0.2 & 1.1 & n.a. & 9.7 \\
\hline & 2 & 0.71018 & 0.00002 & 0.097 & -6.2 & -49.3 & n.a. & 23.9 & 0.4 & 0.7 & n.a. & 10.2 \\
\hline & 3 & 0.70994 & 0.00002 & 0.097 & -5.8 & -46.9 & n.a. & 19.5 & 0.2 & 1.1 & n.a. & 12.6 \\
\hline & 4 & 0.71001 & 0.00004 & 0.092 & -7.5 & -53.9 & n.a. & 21.6 & 0.3 & 0.2 & n.a. & 11.1 \\
\hline & 5 & 0.70999 & 0.00002 & 0.090 & -7.4 & -53.9 & n.a. & 17.5 & 0.3 & 2.4 & n.a. & 8.9 \\
\hline & 6 & 0.70995 & 0.00001 & 0.095 & -7.8 & -56.5 & n.a. & 11.5 & 0.3 & 1.1 & n.a. & 7.3 \\
\hline
\end{tabular}




\section{Continued}

\begin{tabular}{|c|c|c|c|c|c|c|c|c|c|c|c|c|}
\hline & 0 & 0.71050 & 0.00006 & 0.099 & -8.0 & -58.6 & n.a. & 4.6 & 0.2 & 1.1 & n.a. & 7.8 \\
\hline & 1 & 0.70999 & 0.00002 & 0.087 & -6.6 & -48.1 & n.a. & 19.8 & 0.2 & 2.2 & n.a. & 12.5 \\
\hline & 2 & 0.71003 & 0.00003 & 0.089 & -7.1 & -51.9 & n.a. & 21.4 & 0.4 & 0.9 & n.a. & 11.4 \\
\hline \multirow[t]{7}{*}{ MWS2 } & 3 & 0.70999 & 0.00003 & 0.086 & -7.3 & -52.6 & n.a. & 21.9 & 0.4 & 1.0 & n.a. & 11.6 \\
\hline & 4 & 0.71001 & 0.00001 & 0.092 & -7.4 & -53.6 & n.a. & 20.4 & 0.3 & 1.1 & n.a. & 12.0 \\
\hline & 5 & 0.70999 & 0.00002 & 0.090 & -7.6 & -56.6 & n.a. & 10.6 & 0.6 & 2.1 & n.a. & 8.8 \\
\hline & 6 & 0.70999 & 0.00001 & 0.101 & -8.0 & -58.6 & n.a. & 7.8 & 0.3 & 1.2 & n.a. & 7.3 \\
\hline & 0 & 0.70987 & 0.00004 & 0.117 & -7.7 & -57.3 & n.a. & 6.8 & 0.2 & 4.3 & n.a. & 4.4 \\
\hline & 1 & 0.70956 & 0.00002 & 0.142 & -6.6 & -47.3 & n.a. & 23.1 & 0.1 & 1.7 & n.a. & 10.8 \\
\hline & 2 & 0.71028 & 0.00006 & 0.169 & -7.2 & -52.3 & n.a. & 23.9 & 0.4 & 1.6 & n.a. & 10.9 \\
\hline \multirow[t]{7}{*}{ MWS3 } & 3 & 0.70956 & 0.00004 & 0.152 & -7.2 & -51.7 & n.a. & 19.1 & 0.3 & 1.2 & n.a. & 11.7 \\
\hline & 4 & 0.70957 & 0.00003 & 0.147 & -7.3 & -52.5 & n.a. & 17.9 & 0.2 & 0.8 & n.a. & 11.1 \\
\hline & 5 & 0.70980 & 0.00002 & 0.113 & -7.7 & -56.8 & n.a. & 9.7 & 0.4 & 1.7 & n.a. & 6.0 \\
\hline & 6 & 0.71004 & 0.00004 & 0.111 & -8.0 & -59.3 & n.a. & 6.3 & 0.3 & 1.0 & n.a. & 5.2 \\
\hline & 0 & 0.71006 & 0.00003 & 0.102 & -7.1 & -52.6 & 0.2 & 10.1 & 0.2 & 0.5 & n.a. & 8.1 \\
\hline & 1 & 0.70991 & 0.00004 & 0.091 & -7.4 & -54.6 & n.a. & 11.5 & 0.2 & 1.9 & n.a. & 11.4 \\
\hline & 2 & - & - & - & - & - & - & - & - & - & - & - \\
\hline \multirow[t]{7}{*}{ MWS4 } & 3 & 0.71000 & 0.00002 & 0.088 & -7.6 & -55.6 & n.a. & 13.8 & 0.3 & 1.5 & n.a. & 13.4 \\
\hline & 4 & 0.71014 & 0.00003 & 0.089 & -7.5 & -55.2 & n.a. & 13.8 & 0.3 & 0.9 & n.a. & 13.9 \\
\hline & 5 & 0.70998 & 0.00002 & 0.096 & -7.8 & -57.6 & n.a. & 7.8 & 0.3 & 1.5 & n.a. & 6.0 \\
\hline & 6 & 0.71098 & 0.00005 & 0.094 & -8.1 & -58.6 & n.a. & 7.6 & 0.3 & 1.2 & n.a. & 4.4 \\
\hline & 0 & 0.70996 & 0.00008 & 0.108 & -8.0 & -59.0 & n.a. & 4.2 & 0.2 & 0.8 & 14.4 & 13.9 \\
\hline & 1 & 0.70998 & 0.00001 & 0.091 & -6.5 & -47.3 & n.a. & 11.2 & 0.2 & 1.4 & n.a. & 7.4 \\
\hline & 2 & - & - & - & - & - & - & - & - & - & - & - \\
\hline \multirow[t]{7}{*}{ MWS5 } & 3 & 0.70997 & 0.00003 & 0.088 & -7.6 & -55.4 & n.a. & 16.3 & 0.7 & 1.3 & n.a. & 7.8 \\
\hline & 4 & 0.70999 & 0.00002 & 0.084 & -7.6 & -55.7 & n.a. & 12.4 & 0.4 & 1.0 & n.a. & 5.1 \\
\hline & 5 & 0.70997 & 0.00002 & 0.088 & -7.6 & -56.4 & n.a. & 12.0 & 0.4 & 3.4 & 2.8 & 5.0 \\
\hline & 6 & 0.70998 & 0.00001 & 0.095 & -8.0 & -58.6 & n.a. & 6.9 & 0.3 & 1.2 & n.a. & \\
\hline & 0 & 0.71004 & 0.00005 & 0.109 & -8.0 & -58.3 & n.a. & 5.2 & 0.2 & 0.8 & n.a. & 3.8 \\
\hline & 1 & 0.71005 & 0.00003 & 0.077 & -4.8 & -42.2 & n.a. & 22.7 & 0.6 & 2.4 & n.a. & 6.9 \\
\hline & 2 & 0.71003 & 0.00004 & 0.088 & -6.9 & -50.4 & n.a. & 22.4 & 0.4 & 1.2 & n.a. & 12.7 \\
\hline \multirow[t]{4}{*}{ MWS6 } & 3 & 0.71002 & 0.00004 & 0.080 & -7.5 & -54.5 & n.a. & 22.4 & 0.3 & 1.6 & n.a. & 7.5 \\
\hline & 4 & 0.70998 & 0.00005 & 0.086 & -7.5 & -54.4 & n.a. & 22.2 & 0.5 & 0.6 & n.a. & 6.6 \\
\hline & 5 & 0.71002 & 0.00001 & 0.090 & -7.1 & -52.2 & n.a. & 17.7 & 0.3 & 3.1 & n.a. & 5.6 \\
\hline & 6 & 0.71000 & 0.00008 & 0.097 & -7.9 & -57.6 & n.a. & 8.7 & 0.3 & 1.4 & n.a. & 4.6 \\
\hline
\end{tabular}




\section{Continued}

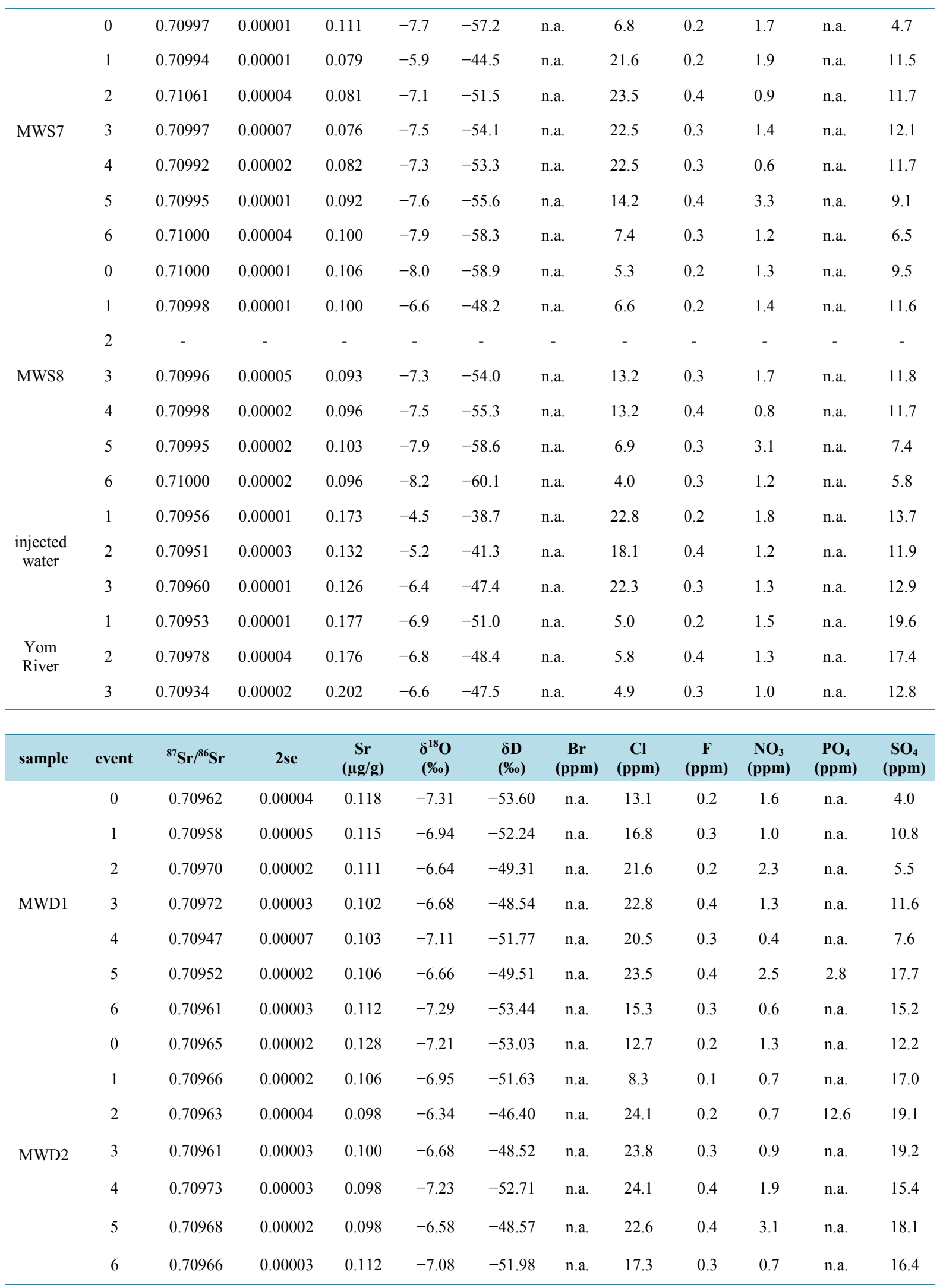




\section{Continued}

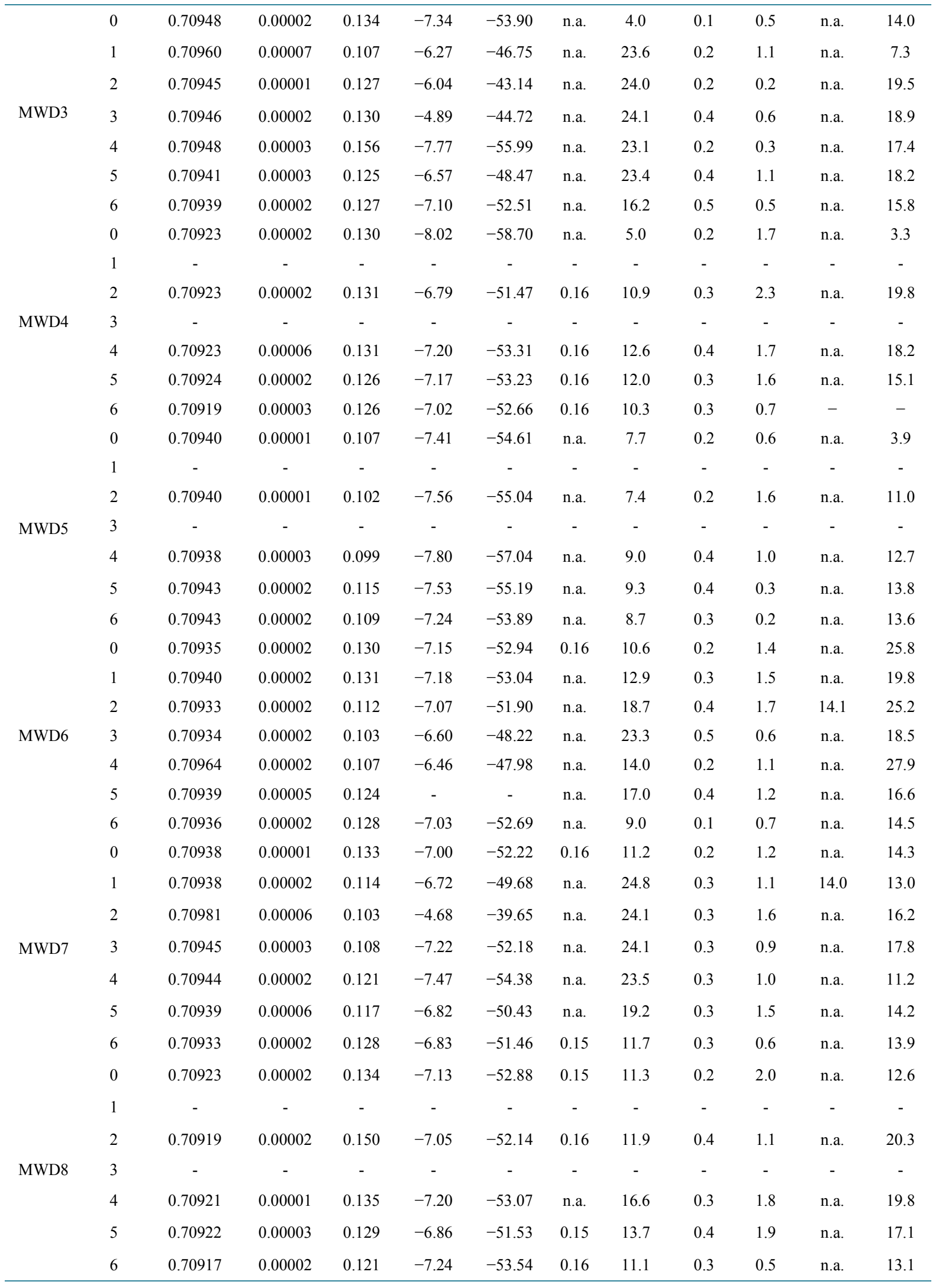


Appendix III. REE concentration in deep aquifer, shallow aquifer, injected water and Yom River from ASR testing in year 2013.

MWS

\begin{tabular}{|c|c|c|c|c|c|c|c|c|}
\hline \multirow{2}{*}{$\mathrm{C}(\mathbf{p p b})$} & \multirow{2}{*}{ sampling date } & \multirow{2}{*}{$\begin{array}{c}\text { before injection } \\
3.08 .13\end{array}$} & \multicolumn{3}{|c|}{ injection } & \multirow{2}{*}{\begin{tabular}{|c|} 
storage \\
13.10 .13
\end{tabular}} & \multicolumn{2}{|c|}{ extraction } \\
\hline & & & 12.09 .13 & 27.09.13 & 9.10 .13 & & 8.11 .13 & 23.11.13 \\
\hline MWS & event & $\mathbf{0}$ & 1 & 2 & 3 & 4 & 5 & 6 \\
\hline \multicolumn{9}{|l|}{ MWS1 } \\
\hline $\mathrm{La}$ & & 0.066 & 0.016 & 0.032 & 0.092 & 0.023 & 0.046 & 0.154 \\
\hline $\mathrm{Ce}$ & & 0.126 & 0.028 & 0.065 & 0.130 & 0.033 & 0.091 & 0.330 \\
\hline $\operatorname{Pr}$ & & 0.010 & 0.002 & 0.004 & 0.003 & 0.004 & 0.010 & 0.040 \\
\hline $\mathrm{Nd}$ & & 0.038 & 0.007 & 0.017 & 0.012 & 0.013 & 0.033 & 0.143 \\
\hline $\mathrm{Sm}$ & & 0.008 & 0.003 & 0.003 & 0.001 & 0.002 & 0.007 & 0.030 \\
\hline $\mathrm{Eu}$ & & 0.014 & 0.011 & 0.009 & 0.008 & 0.012 & 0.013 & 0.019 \\
\hline \multicolumn{9}{|l|}{ MWS 2} \\
\hline $\mathrm{La}$ & & 0.054 & 0.023 & 0.022 & 0.020 & 0.017 & 0.048 & 0.034 \\
\hline $\mathrm{Ce}$ & & 0.084 & 0.043 & 0.037 & 0.033 & 0.023 & 0.076 & 0.063 \\
\hline $\operatorname{Pr}$ & & 0.005 & 0.004 & 0.002 & 0.003 & 0.003 & 0.009 & 0.007 \\
\hline $\mathrm{Nd}$ & & 0.018 & 0.015 & 0.010 & 0.013 & 0.010 & 0.037 & 0.031 \\
\hline $\mathrm{Sm}$ & & 0.004 & 0.003 & 0.002 & 0.003 & 0.003 & 0.007 & 0.005 \\
\hline $\mathrm{Eu}$ & & 0.014 & 0.012 & 0.008 & 0.011 & 0.011 & 0.014 & 0.013 \\
\hline \multicolumn{9}{|l|}{ MWS 3} \\
\hline $\mathrm{La}$ & & 0.024 & 0.133 & 0.080 & 0.043 & 0.034 & 0.073 & 0.052 \\
\hline $\mathrm{Ce}$ & & 0.044 & 0.337 & 0.151 & 0.072 & 0.061 & 0.151 & 0.094 \\
\hline $\operatorname{Pr}$ & & 0.004 & 0.029 & 0.014 & 0.009 & 0.007 & 0.017 & 0.010 \\
\hline $\mathrm{Nd}$ & & 0.017 & 0.110 & 0.055 & 0.035 & 0.026 & 0.069 & 0.038 \\
\hline $\mathrm{Sm}$ & & 0.004 & 0.025 & 0.013 & 0.008 & 0.007 & 0.015 & 0.011 \\
\hline $\mathrm{Eu}$ & & 0.012 & 0.015 & 0.012 & 0.011 & 0.010 & 0.013 & 0.012 \\
\hline \multicolumn{9}{|l|}{ MWS 4} \\
\hline $\mathrm{La}$ & & 0.036 & 0.026 & - & 0.002 & 0.017 & 0.022 & 0.032 \\
\hline $\mathrm{Ce}$ & & 0.071 & 0.036 & - & 0.002 & 0.022 & 0.036 & 0.066 \\
\hline $\operatorname{Pr}$ & & 0.004 & 0.004 & - & 0.000 & 0.003 & 0.005 & 0.007 \\
\hline $\mathrm{Nd}$ & & 0.016 & 0.016 & - & 0.002 & 0.008 & 0.019 & 0.027 \\
\hline $\mathrm{Sm}$ & & 0.004 & 0.004 & - & 0.001 & 0.003 & 0.004 & 0.006 \\
\hline $\mathrm{Eu}$ & & 0.013 & 0.010 & - & 0.004 & 0.011 & 0.015 & 0.013 \\
\hline \multicolumn{9}{|l|}{ MWS 5} \\
\hline $\mathrm{La}$ & & 0.0289 & 0.0291 & - & 0.0615 & 0.0175 & 0.0373 & 0.0422 \\
\hline $\mathrm{Ce}$ & & 0.0540 & 0.0486 & - & 0.0985 & 0.0236 & 0.0770 & 0.0860 \\
\hline $\operatorname{Pr}$ & & 0.0043 & 0.0052 & - & 0.0110 & 0.0038 & 0.0092 & 0.0097 \\
\hline
\end{tabular}




\section{Continued}

$\begin{array}{llllllll}\mathrm{Nd} & 0.0190 & 0.0200 & - & 0.0455 & 0.0108 & 0.0327 & 0.0333 \\ \mathrm{Sm} & 0.0042 & 0.0040 & - & 0.0094 & 0.0024 & 0.0061 & 0.0054 \\ \mathrm{Eu} & 0.0122 & 0.0095 & - & 0.0124 & 0.0126 & 0.0135 & 0.0139\end{array}$

MWS 6

$\begin{array}{llllllll}\mathrm{La} & 0.161 & 0.279 & 0.053 & 0.059 & 0.040 & 0.048 & 0.082 \\ \mathrm{Ce} & 0.314 & 0.530 & 0.091 & 0.117 & 0.065 & 0.087 & 0.151 \\ \mathrm{Pr} & 0.033 & 0.070 & 0.008 & 0.006 & 0.008 & 0.011 & 0.019 \\ \mathrm{Nd} & 0.144 & 0.269 & 0.035 & 0.025 & 0.036 & 0.040 & 0.073 \\ \mathrm{Sm} & 0.028 & 0.057 & 0.007 & 0.006 & 0.007 & 0.009 & 0.012 \\ \mathrm{Eu} & 0.020 & 0.020 & 0.009 & 0.011 & 0.012 & 0.014 & 0.015\end{array}$

\section{MWS 7}

$\begin{array}{llllllll}\mathrm{La} & 0.069 & 0.051 & 0.035 & 0.028 & 0.023 & 0.071 & 0.042 \\ \mathrm{Ce} & 0.142 & 0.084 & 0.060 & 0.046 & 0.029 & 0.129 & 0.077 \\ \mathrm{Pr} & 0.014 & 0.009 & 0.005 & 0.004 & 0.003 & 0.007 & 0.009 \\ \mathrm{Nd} & 0.061 & 0.037 & 0.021 & 0.014 & 0.015 & 0.033 & 0.031 \\ \mathrm{Sm} & 0.011 & 0.008 & 0.004 & 0.004 & 0.003 & 0.005 & 0.008 \\ \mathrm{Eu} & 0.016 & 0.009 & 0.009 & 0.011 & 0.011 & 0.014 & 0.001\end{array}$

MWS 8

\begin{tabular}{lllllllll}
$\mathrm{La}$ & 0.079 & 0.047 & - & 0.027 & 0.018 & 0.030 & 0.034 \\
$\mathrm{Ce}$ & 0.140 & 0.080 & - & 0.048 & 0.026 & 0.053 & 0.069 \\
$\mathrm{Pr}$ & 0.005 & 0.009 & - & 0.005 & 0.002 & 0.005 & 0.008 \\
$\mathrm{Nd}$ & 0.018 & 0.036 & - & 0.019 & 0.012 & 0.019 & 0.028 \\
$\mathrm{Sm}$ & 0.004 & 0.007 & - & 0.004 & 0.001 & 0.004 & 0.006 \\
$\mathrm{Eu}$ & 0.013 & 0.011 & - & 0.012 & 0.011 & 0.014 & 0.000 \\
\hline
\end{tabular}

MWD

\begin{tabular}{ccccccccc}
\hline C (ppb) & $\begin{array}{c}\text { sampling } \\
\text { date }\end{array}$ & before injection & & injection & & storage & \multicolumn{2}{c}{ extraction } \\
\cline { 2 - 8 } & event & $\mathbf{3 . 0 8 . 1 3}$ & $\mathbf{1 2 . 0 9 . 1 3}$ & $\mathbf{2 7 . 0 9 . 1 3}$ & $\mathbf{9 . 1 0 . 1 3}$ & $\mathbf{1 3 . 1 0 . 1 3}$ & $\mathbf{8 . 1 1 . 1 3}$ & $\mathbf{2 3 . 1 1 . 1 3}$ \\
\hline MWD & $\mathbf{0}$ & $\mathbf{1}$ & $\mathbf{2}$ & $\mathbf{3}$ & $\mathbf{4}$ & $\mathbf{5}$ & $\mathbf{6}$ \\
\hline MWD 1 & & & & & & & \\
La & 0.018 & 0.017 & 0.040 & 0.031 & 0.021 & 0.027 & 0.030 \\
Ce & 0.029 & 0.029 & 0.075 & 0.049 & 0.029 & 0.044 & 0.045 \\
Pr & 0.002 & 0.003 & 0.006 & 0.004 & 0.003 & 0.004 & 0.004 \\
Nd & 0.009 & 0.009 & 0.029 & 0.017 & 0.009 & 0.016 & 0.016 \\
Sm & 0.003 & 0.003 & 0.005 & 0.003 & 0.003 & 0.004 & 0.003 \\
Eu & 0.016 & 0.015 & 0.012 & 0.012 & 0.013 & 0.015 & 0.014 \\
\hline
\end{tabular}




\section{Continued}

\section{MWD 2}

$\mathrm{La}$

$\mathrm{Ce}$

$\operatorname{Pr}$

$\mathrm{Nd}$

Sm

Eu

MWD 3

$\mathrm{La}$
$\mathrm{Ce}$
$\mathrm{Nd}$
$\mathrm{Sm}$

$\mathrm{Eu}$

MWD 4

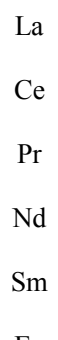

$\mathrm{Eu}$

\section{MWD 5}

$\mathrm{La}$

$\mathrm{Ce}$

$\operatorname{Pr}$

$\mathrm{Nd}$

Sm

$\mathrm{Eu}$

\section{MWD 6}

La

$\mathrm{Ce}$

$\operatorname{Pr}$

$\mathrm{Nd}$

Sm

$\mathrm{Eu}$
0.043

0.084

0.009

0.037

0.008

0.017

0.020

0.033

0.004

0.012

0.004

0.017

0.028

0.049

0.005

0.018

0.005

0.019

0.045

0.075

0.005

0.021

0.004

0.013

0.021

0.036

0.004

0.017

0.003

0.017

$\begin{array}{llllll}0.039 & 0.044 & 0.033 & 0.036 & 0.158 & 0.031 \\ 0.078 & 0.085 & 0.064 & 0.063 & 0.307 & 0.046 \\ 0.008 & 0.009 & 0.005 & 0.007 & 0.036 & 0.005 \\ 0.034 & 0.035 & 0.019 & 0.025 & 0.141 & 0.024 \\ 0.008 & 0.010 & 0.004 & 0.007 & 0.029 & 0.004 \\ 0.015 & 0.011 & 0.010 & 0.015 & 0.021 & 0.016\end{array}$

$\begin{array}{llllll}0.025 & 0.020 & 0.070 & 0.031 & 0.019 & 0.019\end{array}$

$\begin{array}{llllll}0.037 & 0.030 & 0.094 & 0.044 & 0.031 & 0.021\end{array}$

$\begin{array}{llllll}0.003 & 0.002 & 0.008 & 0.005 & 0.004 & 0.002\end{array}$

$\begin{array}{llllll}0.011 & 0.009 & 0.030 & 0.017 & 0.017 & 0.008\end{array}$

$\begin{array}{llllll}0.003 & 0.002 & 0.007 & 0.004 & 0.002 & 0.002\end{array}$

$\begin{array}{llllll}0.015 & 0.013 & 0.012 & 0.017 & 0.016 & 0.015\end{array}$

$\begin{array}{llllll}- & 0.023 & - & 0.051 & 0.036 & 0.035 \\ - & 0.035 & - & 0.081 & 0.057 & 0.043 \\ - & 0.003 & - & 0.006 & 0.003 & 0.005 \\ - & 0.014 & - & 0.021 & 0.013 & 0.014 \\ - & 0.002 & - & 0.006 & 0.004 & 0.003 \\ - & 0.013 & - & 0.017 & 0.016 & 0.015\end{array}$

$\begin{array}{llllll}- & 0.050 & - & 0.037 & 0.035 & 0.027\end{array}$

$\begin{array}{llllll}- & 0.090 & - & 0.063 & 0.067 & 0.035\end{array}$

$\begin{array}{llllll}- & 0.009 & - & 0.006 & 0.007 & 0.004\end{array}$

$\begin{array}{llllll}- & 0.041 & - & 0.020 & 0.030 & 0.013\end{array}$

$\begin{array}{llllll}- & & & & & \\ - & 0.009 & - & 0.006 & 0.006 & 0.002\end{array}$

$\begin{array}{llllll}- & 0.013 & - & 0.013 & 0.015 & 0.014\end{array}$




\section{Continued}

\section{MWD 7}

$\mathrm{La}$

Ce

0.012

0.023

0.016

0.065

0.011

0.033

0.019

0.020

$0.036 \quad 0.026$

0.120

0.016

0.066

0.020

Pr

0.002

0.004

0.002

0.012

0.002

0.006

0.002

$\mathrm{Nd}$

Sm

0.007

$0.015 \quad 0.007$

0.049

0.007

0.023

0.007

$\mathrm{Eu}$

0.002

0.004

0.009

0.002

0.005

0.002

MWD 8

\begin{tabular}{lllllllll}
$\mathrm{La}$ & 0.056 & - & 0.057 & - & 0.027 & 0.055 & 0.038 \\
$\mathrm{Ce}$ & 0.086 & - & 0.089 & - & 0.048 & 0.086 & 0.059 \\
$\mathrm{Pr}$ & 0.005 & - & 0.010 & - & 0.005 & 0.010 & 0.007 \\
$\mathrm{Nd}$ & 0.020 & - & 0.039 & - & 0.022 & 0.044 & 0.027 \\
$\mathrm{Sm}$ & 0.005 & - & 0.008 & - & 0.004 & 0.008 & 0.005 \\
$\mathrm{Eu}$ & 0.016 & - & 0.013 & - & 0.015 & 0.018 & 0.016 \\
\hline
\end{tabular}

Injected water

\begin{tabular}{|c|c|c|c|c|}
\hline $\mathrm{C}(\mathbf{p p b})$ & sampling date & 3.08.13 & 28.08.13 & 12.09.13 \\
\hline \multicolumn{5}{|c|}{ injected water } \\
\hline $\mathrm{La}$ & & 0.095 & 0.107 & 0.023 \\
\hline $\mathrm{Ce}$ & & 0.214 & 0.142 & 0.040 \\
\hline $\operatorname{Pr}$ & & 0.020 & 0.008 & 0.006 \\
\hline $\mathrm{Nd}$ & & 0.079 & 0.026 & 0.021 \\
\hline $\mathrm{Sm}$ & & 0.013 & 0.004 & 0.005 \\
\hline $\mathrm{Eu}$ & & 0.014 & 0.009 & 0.010 \\
\hline
\end{tabular}

\section{Yom River}

\begin{tabular}{ccccccc}
\hline C $(\mathbf{p p b})$ & sampling date & $\mathbf{2 8 . 0 8 . 1 3}$ & $\mathbf{1 1 . 0 9 . 1 3}$ & $\mathbf{2 7 . 0 9 . 1 3}$ & $\mathbf{9 . 1 0 . 1 3}$ & $\mathbf{2 8 . 1 0 . 1 3}$ \\
\hline & Yom River & & & & \\
$\mathrm{La}$ & 1.350 & 2.285 & 0.640 & 1.450 & 0.715 \\
$\mathrm{Ce}$ & 2.680 & 4.375 & 1.265 & 2.910 & 1.380 \\
$\mathrm{Pr}$ & 0.322 & 0.560 & 0.163 & 0.392 & 0.183 \\
$\mathrm{Nd}$ & 1.320 & 2.185 & 0.635 & 1.615 & 0.725 \\
$\mathrm{Sm}$ & 0.286 & 0.476 & 0.148 & 0.363 & 0.157 \\
$\mathrm{Eu}$ & 0.082 & 0.120 & 0.045 & 0.106 & 0.047 \\
\hline
\end{tabular}

